\title{
İCRA VE İFLAS KANUNUNUN ON ALTINCI BABINDAKİ TAKİBİ ŞİKAYETE BAĞLI SUÇLARDA UZLAŞTIRMA KURUMUNUN UYGULANMASININ DOĞURACAĞI SAKINCALAR*
}

\author{
İhsan BAŞTÜRK**
}

$\ddot{O} Z$

Ícra ve Iflas Kanunu (IIIK)'nun on altıncı babında, bazı fiiller suç olarak tanımlanmış; bunlardan bir kısmı ise adli para velveya hapis cezasl yaptırımına bağlanmıştır. Uyuşmazlıkların yargı önüne gitmeden çözümlenmesini amaçlayan bir alternatif uyuşmazlık çözüm mekanizması olan uzlaştırma kurumunun anılan suçlar yönünden uygulanması konusu 2 Aralı 2016 tarihinde Ceza Muhakemesi Kanunu (CMK) 'nda yapılan değişiklik sonrası tartışmalı hale gelmiştir. Nitekim, Yargıtay Ceza Genel Kurulu (CGK) ile 12. Hukuk Dairesi (HD), 19. Ceza Dairesi (CD) ve ilk derece mahkemelerince bu konuda tamamen farklı kararlar verilmiştir. Sonuçta hukuk dünyasında bu konuya ilişkin içtihat farklılığı ortaya çıkmıştır. Bu bağlamda, konunun yargısal kararlar yanında bilimsel görüşler ile de değerlendirilmesi ihtiyacı doğmuştur.

Çalışmamızda öncelikle IIIK'nin on altıncı babında düzenlenen ve takibi şikâyete bağlı olan suçlar bakımından uzlaştırma kurumunun uygulanıp uygulanamayacağ sorusunun cevabı ortaya konulmuştur. Kendine özgü özellikler taşıyan icra ceza muhakemesi dalina dair ilkelerin irdelenmesiyle bu alana katkl verilmesi de amaçlanmıştır.

Anahtar Kelimeler: İcra ceza muhakemesi, İcra ve İflas Kanununda dava ve cezanın düşmesi, mağdur-fail arabuluculuğu (uzlaştırma), alternatif uyuşmazlık çözzümü, icra suçları.

* Çalışmamızda yer verilen düşüncelerin bir kısmı, Yargıtay 19. Ceza Dairesinin 17/1/2019 tarihli ve 2018/6894 E. 2019/410 K. sayılı Karşı Oy yazımızda ifade edilmiştir.

** Dr., Yargitay Üyesi. e-posta: ihsanbasturk@yargitay.gov.tr

ORCID ID: 0000-0002-1236-7040

DOI : 10.34246/ahbvuhfd. 813003

Yayın Kuruluna Ulaştığı Tarih $\quad$ : 20/08/2019

Yayınlanmasının Uygun Görüldüğ̈̈ Tarih: 31/08/2020

Ankara Hacı Bayram Veli Üniversitesi Hukuk Fakültesi Dergisi C. XXIV, Y. 2020, Sa. 4613 
İcra ve İflas Kanununun On Altıncı Babındaki Takibi Şikayete Bağlı Suçlarda...

\begin{abstract}
THE POSSIBLE DRAWBACKS IMPLICATED IN THE PRACTICE OF MEDIATION IN OFFENCES WITHIN THE 16 TH SECTION OF THE ENFORCEMENT AND BANKRUPTCY CODE THAT ARE BOUND TO A COMPLAINT FOR PROSECUTION
\end{abstract}

\begin{abstract}
In the sixteenth section of the Code of Enforcement and Bankruptcy some acts were defined as offences; some of these offences then are tied up with sanctions of monetary fine or imprisonment. Victim-offender mediation is an alternative dispute resolution mechanism that aims resolution of disputes without having to appear before the judiciary. The application of victim-offender mediation to the above-mentioned offences has been a topic of controversy after December 2, 2016 due to a change in Criminal Procedure Code. As a matter of fact, the judgements made on this topic by the 12th Civil Chamber, 19th Criminal Chamber and first instance criminal courts were utterly differing with the judgement of the Criminal Assembly of the Court of Cassation. Ultimately, there risen jurisprudence differences regarding this matter in the world of legal practice. In this context, besides consideration of legal judgements, there emerged a need to approach the topic from scientifically oriented perspectives as well.

In our study, an answer to the question of whether the institution of victimoffender mediation can be used for the offences organized by the sixteenth section of the Code of Enforcement and Bankruptcy is revealed. Also, through scrutinizing the principles for the criminal procedure of enforcement law that has peculiar qualities of its own, some contribution to the field is also aimed.
\end{abstract}

Keywords: Criminal procedure of enforcement law, dismissal of the case and penal on Code of Enforcement and Bankruptcy, victim-offender mediation, alternative dispute resolution, offences on enforcement law.

\title{
GÍRIŞ
}

İIK'nin on altıncı babında (md. 331-354) cezai hükümlere yer verilmiştir. İ̇K'nin belirtilen on altıncı babı dışında 76. maddesinde tazyik hapsini gerektiren mal beyanında bulunmamak fiilinin, 310 ve 311. maddelerinde ise iflâs suçlarının tanımlandığını ayrıca hatırlatalım. Konumuzun odak noktasını oluşturan uzlaştırma kurumunun uygulanması İIK' de yer verilen suçlardan sadece takibi şikâyete bağlı olan icra suçları bakımından tartışmaya 
açıktır. ${ }^{1}$ Bu itibarla Kanun'un 331, 332, 333/a, 334, 337/a, 338/1 ve 345/a maddelerindeki icra suçları incelememizin kapsamını oluşturmakta; diğer icra ve iflas suçları ile icra fillleri ise çalışmamızın sınırı dışında kalmaktadır. ${ }^{2}$

CMK'nin 253/3. maddesinde 2 Aralık 2016 tarihinde yürürlüğe giren değişiklik ${ }^{3}$ konuya ilişkin tartışmaları başlatan gelişme olmuştur. Uzlaştırma uygulamasına dair anılan maddenin ilk cümlesi; "Soruşturulması ve kovuşturulması şikâyete bağlı olsa bile, etkin pişmanlık hükümlerine yer verilen suçlarda ...uzlaştırma yoluna gidilemez" şeklinde iken;4 "İIK' deki anılan fiiller yönünden uzlaştırma hükümlerinin uygulanamayacağı" yönündeki içtihatlar yerleşik idi. Ancak, söz edilen değişiklik ile "etkin pişmanlık hükümlerine yer verilen suçlarda da uzlaştırmanın mümkün hale getirilmesi" üzerine CGK ile 12. HD ve 19. CD bu konuda farklı kararlar vermeye başlamıştır. Diğer taraftan, Yargıtay özel daire kararlarına karşı ilk derece mahkemelerince verilmiş direnme (1srar) kararları da mevcuttur. ${ }^{5}$

İIK'nin konumuzla ilgili "Davanın ve cezanın düşmesi ile ceza verilemeyecek haller" başılılı 354. maddesinin birinci fikrası şöyledir:

"Kanunun bu babinda yazll suçlardan takibi şikayete bağlı olanların müstekisi feragat eder veya borcun itfa edildiği sabit olursa dava ve bütün

1 Tazyik hapsini gerektiren fiiller Kanun'un 338/2, 340, 341, 343 ve 344. maddelerinde; disiplin hapsini gerektiren fiil 339.; resen kovuşturulan icra suçları ise, 333, 335, 336, 337, 342 ve 345/b maddelerinde düzenlenmiştir. IIIK'nin 331, 332, 333/a, 334, 337/a, 338/1 ve 345/a maddelerinde ise takibi şikâyete bağlı olan icra suçlarına yer verilmiştir.

2 İIK'deki cezai hükümlerin kapsamlı bir değerlendirmesi için ayrıca bkz. ERMENEK, İbrahim: “İcra ve İflâs Kanunu'nda Öngörülen Cezaî Hükümler Bakımından Ne Bis İn İdem İlkesinin Uygulama Alanı” Türkiye Adalet Akademisi Dergisi, Sa.19, Ekim 2014, s. 279320.

3 Bkz. Resmi Gazete (RG), 2/12/2016/ 29906.

4 Etkin pişmanlık hükümlerine yer verilen bazı suçların uzlaştırmaya çok elverişli olmasına rağmen bu suçlarda uzlaștırma yolunun kapatılmasının isabetli olmadığına ilișkin ayrıca bkz. ÖZBEK, Mustafa Serdar: "Ceza Muhakemesi Kanununda Yapılan Değişiklikler Çerçevesinde Mağdur Fail Uzlaştırmasının Usûl ve Esasları” Ankara Üniversitesi Hukuk Fakültesi Dergisi, C. 56, Sa. 4, s. 157. (ÖZBEK, M. S.).

5 İstanbul 5. İcra Mahkemesi Yargitay 19. Ceza Dairesinin 8/3/2018 tarih ve 2017/2359, 2018/2495 sayılı ilamına direnme yoluyla verdiği kararında (özetle) şu gerekçelere yer vermiştir:

“...IIIK'nin 354. maddesindeki müessesenin etkin pişmanlık değil özel uzlaşma müessesesi olduğu... icra ceza suçlarının CMK'deki genel uzlaşma hükümlerine göre değil de İIK'deki özel uzlaşma hükümlerine tabi olduğunun pratik göstergesi de icra ceza suçlarında fiiliyatta neredeyse hiçbir uzlaşmanın sağlanamamasıdır..."

Bkz. İstanbul 5. İcra Ceza Mahkemesi, 3/5/2018, 2018/185, 2018/223. (UYAP). 
İcra ve İflas Kanununun On Altıncı Babındaki Takibi Şikayete Bağlı Suçlarda...

neticeleriyle beraber ceza düşer.”

$\mathrm{Bu}$ normun hukuki niteliğinin belirlenmesi ve dolayısıyla icra ceza mahkemelerince uygulanacak muhakeme usulünün irdelenmesi, konunun çözümü bakımından önem taşımaktadır. Öte yandan, İIK' nin on altıncı babında düzenlenen takibi şikâyete bağlı suçlar yönünden uzlaştırma kurumunun uygulanmasına dair içtihatların, 2005 yılından günümüze değin izlediği seyir hatırlanmalıdır:

CGK, Çek Kanunu'na aykırılık suçlarına ilişkin 2005 tarihli içtihadında (özetle) "İIK'nin 354. maddesi amir hükmünün uzlaşmayı kendi bünyesinde barındırdığ 1 , İIK' de uzlaştırmaya ilişkin hükümlerin zaten yer aldığı" görüşüne yer vermiştir. ${ }^{6}$ Yargıtay 16. HD ise, CGK'nin bu içtihadından hareketle; “...IÏK'nin 354. maddesi amir hükmünün uzlaştırmayı kendi bünyesinde barındırdığ 1 dikkate alındığında, icra mahkemesince uzlaştırma konusunda herhangi bir işlem yapılmasına gerek bulunmadığına" içtihat etmekteydi. ${ }^{7}$

CMK'nin 253/3. maddesinde yapılan 2 Aralık 2016 tarihli değişiklikle "etkin pişmanlık hükümlerine yer verilen suçlarda uzlaştırma yoluna gidilemeyeceği" ilkesi yürürlükten kaldırllmıştır. Bu değişiklik, etkin pişmanlık hükümlerine yer verilen suçlar yönünden de uzlaştırmanın mümkün hale geldiği düşüncesinin ortaya çıkmasına ${ }^{8}$ ve CGK'nin söz edilen içtihadında değişime sebep olmuştur. Söz edilen içtihat değişim sürecini şöyle özetleyebiliriz:

a) CGK, anılan kanuni değişiklikten hareket ederek 2017 yılında (özetle); “...Kanun'un 354. maddesinin birinci fikrasında davanın ve cezanın düşmesine imkân sağlayan özel bir etkin pişmanlık hükmüne yer verilmiş olup; uzlaştırmanın soruşturma ve kovuşturmalarda mutlaka öncelikle uygulanması zorunlu bir maddi ceza ve ceza muhakemesi hukuku kurumu olmasi ile İIK'nin 354. maddesinin yerine geçip anılan maddenin uygulanmasını ortadan kaldırmaması gerekçesiyle anılan suçlar bakımından öncelikle uzlaştırma hükümlerinin uygulanması gerektiğine" içtihat etmiştir. ${ }^{9}$

6 CGK 5/7/2005, 2005/10-84-90. (UYAP).

7 16. HD, 07.07.2008, 2008/5180, 2008/4928. (UYAP).

86763 sayılı Kanun değişikliği sonrası uzlaştırma kurumu uygulamasına dair kapsamlı değerlendirmeler ve öneriler için bkz. ÖZBEK, Veli Özer: "Ceza Muhakemesi Hukukunda Uzlaştırma Kurumunun 6763 Sayılı Kanun Hükümleri Çerçevesinde Değerlendirilmesi”, Ceza Hukuku Dergisi, Sa. 32, Aralık 2016, s. 7-28. (ÖZBEK, V.Ö. 2016).

9 CGK 14/3/2017, 2017/19-7, 2017/137 (UYAP).

616 Ankara Hacı Bayram Veli Üniversitesi Hukuk Fakültesi Dergisi C. XXIV, Y. 2020, Sa. 4 
b) Yargitay 19. CD, CGK'nin 2017 tarihli bu yeni içtihadını benimseyerek (özetle) “...IİK’nin on altıncı babındaki takibi şikâyete bağlı suçlarda öncelikle uzlaştırma usulünün uygulanması gerektiğine” 2019 yılına gelinceye değin içtihat etmekteydi. ${ }^{10}$ Bölge Adliye Mahkemeleri (BAM)'nin de bu içtihada uygun kararlar verdikleri gözlemlenmiştir. ${ }^{11}$

c) İstanbul 5. İcra Ceza Mahkemesi ise, anılan suçlarda uzlaştırma usulünün uygulanmayacağı kanaatiyle 19. CD'nin söz edilen görüşteki bozma ilamına direnme kararı vermiş ve uyuşmazlık yeniden CGK'nin gündemine taşınmıştır. ${ }^{12}$

10 “...02.12.2016 tarihli Resmi Gazete'de yayımlanarak yürürlüğe giren 6763 sayıl1 Kanun'un 34. maddesiyle Ceza Muhakemesi Kanunu'nun 253. maddesinde değişiklik yapılarak madde içeriğinden "etkin pişmanlık hükümlerine yer verilen suçlar ile" ibaresinin çıkarılması nedeniyle özel bir etkin pişmanlık hükmü olan 2004 İcra ve İflas Kanunu'nun 354. maddesinin aynı Kanun'un 337/a maddesinde düzenlenen suç yönünden uzlaştırma kurumunun uygulanmasına engel teşkil etmemesi, suçun işlenmesinden sonra fail ile mağdur arasındaki çekişmeyi bir uzlaştırmacının girişimiyle kısa zamanda tarafların özgür iradeleriyle ve adli merciler daha fazla meşgul edilmeden sonuçlandırmayı amaçlayan uzlaştırmanın soruşturma ve kovuşturmalarda mutlaka öncelikle uygulanması zorunlu bir maddi ceza ve ceza muhakemesi hukuku kurumu olması ve İcra ve İflas Kanunu'nun 354. maddesinin yerine geçip anılan maddenin uygulanmasını ortadan kaldırmaması karşısında, sanık hakkında 6763 sayılı Kanun'un 34. maddesiyle değişik CMK'nın 253, 254. maddelerinin uygulanması zorunluluğu, ...bozmayı gerektirmiş... “ Yargitay 19. CD. 5/4/2018, 2017/2399, 2018/4114. Aynı yönde bkz. Yargitay 19. CD. 2018/3069, 2018/4132 (UYAP).

11 "Hüküm tarihinde yürürlükte bulunan 6763 sayılı Ceza Muhakemesi Kanunu İle Bazı Kanunlarda Değișiklik Yapılmasına Dair Kanunun 34. maddesi ile değișik CMK'nın 253/1-3 maddesi uyarınca, "etkin pişmanlık hükümlerine yer verilen suçlar" ibaresinin madde metninden çıkartılması nedeniyle istinaf incelemesine konu suçun uzlaşma kapsamına alınması, 6763 sayılı Kanunun 35. maddesi ile değişik CMK'nın 254. maddesi uyarınca "Kamu davası açıldıktan sonra kovuşturma konusu suçun uzlaşma kapsamında olduğunun anlaşılması halinde kovuşturma dosyası uzlaştırma işlemlerinin 253. maddede belirtilen esas ve usule göre, yerine getirilmesi için uzlaştırma bürosuna gönderilir" şeklindeki düzenleme ile Türk Ceza Kanunu'nun 7/2 maddesindeki "suçun işlendiği zaman yürürlükte bulunan kanun ile sonradan yürürlüğe giren kanunların hükümleri farklı ise, failin lehine olan kanun uygulanır ve infaz olunur" hükmü gözetilerek, CMK'nun 6763 sayılı kanun ile değişik 253 - 254. maddeleri uyarınca uzlaştırma usulüne göre işlem yapılmaması, hüküm gerekçesinde de önceki ve sonraki kanunlar yönünden değerlendirme yapılmaması nedeniyle hükmün bu hususta gerekçesiz olması;

Hukuka aykırı ve istinaf talebi bu itibarla yerinde görülmekle, sair yönleri incelenmeksizin Ceza Muhakemesi Kanununun 230, 280/1-b, 289/1-g maddeleri uyarınca hükmün BOZULMASINA...” Ankara BAM 9. CD., 18/4/2017, 2017/1175, 2017/1251. Aynı yönde Ankara BAM 9. CD, 11/4/2017, 2017/1179,2017/1137. (UYAP).

12 İstanbul 5. İcra Ceza Mahkemesi, 3/5/2018, 2018/185, 2018/223. (UYAP). Anılan karar, CGK'nin 2019/234 E. sırasında kayıtlı olup henüz karara bağlanmamıştır (UYAP). 
İcra ve İflas Kanununun On Altıncı Babındaki Takibi Şikayete Bağlı Suçlarda...

d) 2019 yılından itibaren icra suçlarından doğan uyuşmazlıklara bakmakla görevli13 Yargitay 12. HD ise, CGK'nin 2017 tarihli içtihadına uymayarak; "İIK'nin on altıncı babındaki takibi şikâyete bağlı suçlarda uzlaştırma usulünün uygulanamayacağına" içtihat etmiştir. ${ }^{14}$

Özetlediğimiz üzere, aynı konuda birbiri ile taban tabana zıt olan Yargıtay özel daireleri ile Ceza Genel Kurulunun içtihatları ve ilk derece mahkemelerinin kararları bulunmaktadır. Öte yandan, icra suçlarında uzlaştırma kurumunun uygulanması" konusunun bilimsel çalışmalarda yeterli düzeyde irdelenmediği müşahede olunmuştur. Bir düşünceye göre; 6763 sayılı Kanun ile etkin pişmanlık hükümleri uzlaştırmanın uygulanmasına engel olmaktan çıkartıldığ için, uzlaştırma hükümlerinin uygulanmasının mümkün olduğu ileri sürülmektedir. ${ }^{15} 6763$ sayılı Kanun değişikliğinden önce dahi icra suçlarında uzlaştırma usulünün tartışmasız şekilde uygulanabileceğinin ileri sürüldüğü görülmekte idi. ${ }^{16}$ Diğer taraftan, bu suçlarda uzlaştırma yoluna gidilemeyeceği, bunun pratik bir yararının olmadığı da savunulmaktadır. ${ }^{17}$ Bir diğer düşünceye göre ise, CMK'nin 253/2. maddesindeki düzenleme, birinci fikrayı (TCK'dekiler diye ayırmaksızın tüm takibi şikâyete bağlı suçları) saklı tuttuğunu hatırlatmakta olup; buradan hareketle özel kanunlarda düzenlenen şikâyete bağlı suçlar uzlaştırma kapsamındadırlar. ${ }^{18}$ Söz edilen

131 Şubat 2019 tarihinden itibaren İIK'nin on altıncı babında, Kanun'un 331 ila 354. maddeleri arasında düzenlenen suçlar hakkında verilen hüküm ve kararların kanun yolu denetimini yapmakla Yargıtay 12. HD; İ̈K' de tanımlanan diğer fiillere ilişkin uyuşmazlıklar yönünden ise 19. CD görevlendirilmiştir.

Yargıtay’ın 2019 yılı işbölümüne dair Yargıtay Büyük Genel Kurulu kararı için bkz. Resmi Gazete (RG.) 31/1/2019, 30672.

14 12. HD. 27/2/2019, 2019/1609, 2019/3078; 6/3/2019, 2019/2780, 2019/3633 (UYAP).

15 Bu düşüncenin 5941 sayılı Çek Kanunu yönünden savunulmakta ise de bu Kanun'un 5. maddesinin İIK'nin muhakeme usulüne atıf yapması sebebiyle İIK'nin on altıncı babındaki suçlar yönünden de aynı görüşün ileri sürüldüğü söylenebilecektir. Bkz. EKİCİ ŞAHİN, Meral/ YEMENICI, Kürşat: "6763 Sayılı Kanunla Yapılan Değişiklikler Işı̆̆ında Ceza Muhakemesi Hukukunda Uzlaştırma”, Erzincan Üniversitesi Hukuk Fakültesi Dergisi, C. XIII, Sa. 1, 2018, s. 471.

16 Söz edilen görüşün hukuki dayanaklarının ifade edilmediğini belirtmek durumundayız. Bkz. KAYMAZ, Seydi/ GÖKCAN, Hasan Tahsin: Uzlaşma ve Önödeme, Seçkin Yayınevi, İkinci bask1, Ankara 2007, s. 334. Aynı yönde bkz. ÖZBEK, M. S., s. 157. YILDIZ, Hasan: İcra ve İflas Suçları, Yayınlanmamış Yüksek Lisans Tezi, Selçuk Üniversitesi Sosyal Bilimler Enstitüsü, Konya 2007, s. 241.

17 Ayrıca bkz. SARI, Rıfat: İcra Suçları, Yayınlanmamış Yüksek Lisans Tezi, Ankara Üniversi0tesi Sosyal Bilimler Enstitüsü, Ankara 2011. ÇETİNTÜRK, Ekrem: Onarıcı Adalet ve Ceza Adalet Sisteminde Uzlaştırma, Adalet Yayınevi, Ankara 2017.

18 KUNTER, Nurullah/ YENISEY, Feridun/ NUHOĞLU, Ayşe: Bir Muhakeme Dalı Olarak 
görüşlerin, sorunun anlaşılmasına katk1 sağlayabilecekleri kuşkusuz olmakla birlikte İİK'nin on altıncı babındaki takibi şikâyete bağlı suçlarda uzlaştırma hükümlerinin uygulanabilirliği konusunun kapsamlı ve derin kesitli olarak irdelenmemiş oluşu dikkat çekicidir. Öte yandan farklı yarg1 kararları da ilk derece mahkemelerinin isabetli karar vermesini neredeyse imkânsız kılmaktadır. Çek Kanunu'na aykırılık fiilleri bakımından da -uzlaştırma usulü uygulanmasa dahi- icra ceza mahkemelerinin muhakeme usulünün uygulanacağ 1 ilkesi ${ }^{19}$ gözetildiğinde, konunun uygulama alanının genişlediği görülmektedir. Gerçekten, 2018 yılında ceza mahkemelerince toplam 4.067.380 karar verildiği ve bu kararlardan 203.687'sinin İİK'ye aykırılık fiillerine, 79.923'ünün ise Çek Kanunu'na aykırılık fiillerine ilişkin olduğu nazara alındığında konunun önemi istatistiksel verilerle de ortaya çıkmaktadır. ${ }^{20}$

\section{UZLAŞTIRMA KURUMU: MAĞDUR-FAIIL ARABULUCULUĞU}

Mağdur-fail arabuluculuğu (victim-offender mediation) yani uzlaştırma Anglo-Amerikan hukuku kaynaklı olup; farklı uygulanma biçimleri olan ve ceza muhakemesinde şüpheliyi sistem dışına çıkarıcı (diversion) fonksiyonuyla, onarıc1 adalet (restorative justice) modellerinden birisini oluşturmaktadır. ${ }^{21}$ Uzlaştırma, -devletin cezalandırma hakkını ortadan kaldıran

Ceza Muhakemesi Hukuku, Onsekizinci bask1, Beta Yayınevi, İstanbul 2010, s. 1236.

195941 sayılı Çek Kanunu'nun 'Ceza sorumluluğu, çek düzenleme ve çek hesabı açma yasağ1 "başlıklı 5/1. maddesinin (konumuzla ilgili bölümleri) şöyledir:

“...Koruma tedbiri olarak verilen çek düzenleme ve çek hesabı açma yasağı kararlarına karşı yapılan itirazlar bakımından 9/6/1932 tarihli ve 2004 sayılı İcra ve İflas Kanununun 353 üncü maddesinin birinci fikrası hükmü uygulanır. Bu suçtan dolayı açılan davalar icra mahkemesinde görülür ve İcra ve İflas Kanununun 347, 349, 350, 351, 352 ve 353 üncü maddelerinde düzenlenen yargılama usulüne ilişkin hükümler uygulanır..."

5941 md. 5/10: (Değișik: 15/7/2016-6728/63 md.) Birinci fikrada tanımlanan suç nedeniyle, ön ödeme, uzlaşma ve hükmün açıklanmasının geri bırakılmasına ilişkin hükümler uygulanmaz.

5941 say1lı Çek Kanunu için bkz. RG. 20/12/2009, 27438.

20 Adli İstatistikler 2018, T.C. Adalet Bakanlı̆̆ 1 , Ankara 2019, s. 37, 46-49.

http://www.adlisicil.adalet.gov.tr/istatistik_2018/istatistik2018.pdf (Erişim tarihi: 6/7/2019).

21 WALDMAN, Ellen A. : "Healing Hearts or Righting Wrongs?: A Meditation on The Goals of "Restorative Justice" Hamline University, Journal of Public Law \& Policy, 2004, Vol. 25, s. 355-374. http://law.hamline.edu (Erişim tarihi: 7/5/2019).

Bu konuda ayrıca bkz. ŞAHİN, Cumhur: "Ceza Muhakemesinde Uzlaşma”, Selçuk Üniversitesi Hukuk Fakültesi Dergisi, Konya 1998, C. 6, Sa. 1-2, s. 221-297. ÖZBEK, M. S., s. 127-131. ÇETINTÜRK, s. 59-100. YENISEY, Feridun: Ceza Muhakemesi Hukukunda 
bir sebep olması itibariyle maddi ceza hukukuna dair yönü de bulunmakla birlikte-22 uyuşmazlıkların alternatif bir çözüm yolu olarak tarafların bir edim karş1lı̆ğnda veya edim olmadan anlaşarak muhakemeyi sona erdirmelerini amaçlayan bir muhakeme hukuku kurumudur. ${ }^{23}$ Uzlaştırmanın, toplumda suç ile bozulan düzeni yeniden ihdas eden yeni bir "yaptırım benzeri kurum" olduğu da ileri sürülmektedir. ${ }^{24}$ Uzlaştırma, fail bakımından muhakemenin sona ermesini; mağdur açısından ise onun suçtan doğan mağduriyetinin giderilmesini sağlamaktadır. Bu bağlamda, mağdur-fail uzlaşması temelini onarıcı adalet düşüncesinde bulmaktadır. Öte yandan, uzlaştırma kurumunun ceza muhakemesindeki değişimin ve medeni muhakemeyle yakınlaşmanın bir yansıması olarak süjeler arasında işbirliğiyle ortaya çıkan bir usûl olduğu da ifade edilmektedir. ${ }^{25}$

Alternatif çözüm yolları, adalete erişimde üçüncü dalga olarak benimsenerek; teşvik edilmesi gerektiği ifade edilmektedir. ${ }^{26}$ Uzlaştırma ise, geleneksel ceza yargılamasını tamamlayan, esnek ve sorun çözücü bir seçenek olarak önerilmektedir. ${ }^{27}$ Uzlaştırma benzeri alternatif çözüm modelleri ve tekniklerinin suçtan doğan mağduriyeti giderici etkisi de bulunmaktadır. ${ }^{28}$ Geleneksel olarak adlandırılabilecek mağdur-fail adalet sisteminin birçok yönden yetersiz kaldığı ve batı dünyasının her yerinde cezai adaleti gözeten çözümlenmemiş davaların varlığı gerekçesiyle onarıcı adalet modellerine daha çok önem verildiği de haklı olarak ifade edilmektedir. ${ }^{29}$ Onarıcı adalet

Uzlaşma (Uzlaştırmacı Eğitimi, Rehber Kitapçı), http:www.uzlaşma.adalet.gov.tr (Erişim tarihi: 8/5/2019).

22 KUNTER/ YENISEY/ NUHOĞLU, s. 1232.

${ }_{23}$ Bu konuda ayrica bkz. CENTEL, Nur/ ZAFER, Hamide: Ceza Muhakemesi Hukuku, Yenilenmiş ve gözden geçirilmiş 15. Bası, Beta Basım, Yayım, Dağıtım A.Ş., İstanbul 2018, s. 550-551.

24 KUNTER/ YENISEY/ NUHOĞLU, s. 1232.

25 ŞAHIN, s. 221-222.

26 TREBILCOCK, Michael J./ DANIELS, Ronald J.: Rule of Law Reform and Development Charting the Fragile Path of Progress, Edward Elgar Publishing Limited, Cheltenham Northampton 2008, s. 248.

27 ÖZBEK, M. S., s. 127.

28 Bkz. ÖZBEK, V.Ö., 1999, s. 299. Bu konuda ayrıca bkz. NUHOĞLU, Ayşe: "Ceza Hukukunda Zararın Telafi Edilmesi” Prof. Dr. Kenan Tunçomağ'a Armağan, IÜHHF Eğitim Öğretim ve Yardımlaşma Vakfı Yayını No: 4, İstanbul 1997, s. 336-348.

29 BERZINS, Andrejs/ LINDSAY, Mac: "Mağdur Fail Uzlaşmas1 (Victim-Offender MediationV.O.M) Seminerinde Sunulan Tebliğ", Ankara, 12 Haziran 2008.

http://www.undp.org.tr/demGovDocs/MediationCriminalJustice/mac_lindsay.doc (Erişim tarihi: 8/5/2019). 
esasına dayanan deneyimlerin özellikle genç suçluluğu gibi alanlarda temel uygulama aracı haline gelerek gelecekteki ceza muhakemesi hukukuna yön verdiği vurgulanmaktadır. ${ }^{30}$

Uzlaştırma, öncelikle uyuşmazlığın süratle çözümlenmesine imkân sağlama aracı iken; ${ }^{31}$ mağdurun haklarının da gözetilerek toplumsal adalet düşüncesinin ve toplumsal barışın sağlanması bakımından da önemli işlev yüklenmektedir. ${ }^{32}$ Uzlaştırma, suçun neticelerine yoğunlaşarak, adalet sürecine mağdur, fail ve onların aileleri ile toplumun katılımının önemini vurgulayan; ${ }^{33}$ barışçıl bir uyuşmazlık çözüm mekanizmasıdır.

Uzlaştırma kurumunda iki temel unsurun bulunduğu ileri sürülmekte olup; bunlardan birincisi tarafsız üçüncü bir kişinin uyuşmazlığın çözümüne yardımcı olması; ikincisi ise bu kişinin çözüm için tarafları zorlayamamasıdır. Buna göre uzlaştırma, "tarafsız bir kişinin (uzlaştırmacı) yardımıyla güvenli ve denetimli bir ortamda mağdur ile failin uyuşmazlığa karşılıklı kabul edilebilir bir çözüm bulabilmek amaciyla bir araya gelmesine imkân sağlayan bir süreç" olarak tanımlanabilir. ${ }^{34}$

\subsection{Uzlaşma ve Uzlaştırma Kavramları}

CMK' de "uzlaştırma" başlığı altında düzenlenen, uzlaşmanın sadece bir şekli olan "mağdur-fail uzlaşması" kurumudur. ${ }^{35}$ Karşılaştırmalı hukukta bu

30 ASHWORTH, Andrew: The Criminal Process An Evaluative Study, Second Edition, Oxford University Press, New York 1998, s. 315.

31 FEYZİĞLU, Metin: “Uzlaştırma Teklifi ve Taraflara Bildirilmesi” Uğur Alacakaptan'a Armağan Cilt I, İstanbul Bilgi Üniversitesi Yayınları, İstanbul Haziran 2008, s. 333.

32 Uzlaştırma sonucu ortaya çıkan hükmün toplumda daha fazla kabul göreceğine dair bkz. ŞAHIN, s. 233.

CMK'nin 253. maddesinde değişiklik yapan 6763 sayılı Kanuna ilişkin madde gerekçesinde bu husus şöyle ifade edilmiştir:

"Kapsamın geniş tutulmasıyla, şüphelilerin doğrudan kamu davası ve cezai yaptırımlar yerine, ecza muhakemesinin onarıcı adalete dayanan kurumlarıyla karşılaşmaları amaçlanmaktadır. Böylelikle, suçun işlenmesiyle bozulan toplumsal düzen, taraflar arasında sağlanan barış yoluyla yeniden tesis edilmektedir. Ayrıca, uyuşmazlıkların alternatif usuller uygulanarak mağdur odaklı bir yaklaşımla giderilmesi, geleneksel muhakeme yoluna nazaran yargı sistemini rahatlatan ekonomik faydalar da sağlamaktadır.” Gerekçe için bkz. https:// mevzuat.tbmm.gov.tr/mevzuat/faces/kanunmaddeleri?pkanunlarno=204725\&pkanunnumar asi=6763 (Erişim tarihi: 9/5/2019).

33 ÇETINTÜRK, s. 106.

34 ERİ̧, Uğur: Ceza Muhakemesi Hukukunda Uzlaştırma ve Uzlaştırma Eğitimi, Türkiye Barolar Birliği Dergisi, Sa. 137, 2018, s. 243.

35 CMK' de yer verilen kurumun "mağdur-fail uzlaşması " adlı kurum olup; "uzlaştırma” başlığıyla düzenlenmesinin hatalı olduğuna dair ayrıca bkz. CENTEL/ZAFER, s. 549-550. 
kurumu ifade etmek üzere kullanılan "mediation" terimini daha iyi karşıladığ1 düşünülen ve amaçtan ziyade bir usulü akla getiren "arabuluculuk" teriminin hem kurumu daha iyi ifade ettiği hem de mağdur açısından anlaşılır ve kabul edilebilir olduğu haklı olarak ifade edilmektedir. ${ }^{36} \mathrm{CMK}$ 'nin tercih ettiği "uzlaşma" terimi 6763 sayılı Kanun ile "uzlaştırma" olarak değişiklik geçirmiş olsa da söz edilen kurumun adı "uzlaştırma"; bu kurumun uygulanmasının amaca ulaşması sonucunda ulaşılan durum (olgu) "uzlaşma" ve nihayet bu süreci yürüten kişi ise "uzlaştırmacı" olarak adlandırılacaktır. ${ }^{37}$

\subsection{Ceza Adalet Sistemimizde Uzlaştırma}

Kamu davasının mecburiliği, tasarruf edilmezlik gibi ceza muhakemesinin temel ilkelerine istisna oluşturan ${ }^{38}$ uzlaştırma kurumuna Türk hukukunda ilk kez 5271 sayılı CMK'de (md. 253-254), 5395 sayılı Çocuk Koruma Kanunu (ÇKK)'nda (md. 24) ve 5237 sayılı Türk Ceza Kanunu (TCK)'nda (m. 73) 1 Haziran 2005 tarihinden itibaren adlî yargının yükünü hafifletmek adına yer verilmiştir. ${ }^{39}$ Uzlaştırma kurumu çocuklar bakımından ÇKK ile ayrıca düzenlenmiş iken; 5560 sayılı Kanunla yapılan değişiklikle ${ }^{40}$ yetişkinlerle

Bir düşünceye göre ise, Kanunda uzlaşma teklifi denilmesi yanlıştır. Çünkü, teklifi yapan uzlaşma yolunun tarafı değildir. Dolayısıyla, uzlaşmak istememekte; tarafları uzlaştırmayı denemektedir. Nitekim ilgili Yönetmeliğin başlığında da uzlaşmanın değil; uzlaştırmanın uygulamasından söz edilmektedir. Bkz. FEYZİOĞLU, s. 332.

(Mülga) Ceza Muhakemesi Usulü Kanununa Göre Uzlaştırmanın Uygulanması Hakkında Yönetmelik (Uzlaşma Yön.) için bkz. RG. 26.07.2007/27200.

Ceza Muhakemesinde Uzlaştırma Yönetmeliği (Uzlaştırma Yönetmeliği) için bkz. RG. 5/8/2017/ 30145 .

36 Terim konusunda ayrica bkz. ÇETINTÜRK, s. 355- 357.

6763 sayılı Kanun ile uzlaştırma kurumunda hem terimsel hem kurumsal hem de içeriğe yönelik bir değişikliğe gidildiği ifade edilmektedir. Bkz. ÖZBEK, V.Ö., 2016, s. 8.

37 Krş. ÇETINTÜRK, s. 355.

38 Uzlaştırmanın ceza ve ceza muhakemesinin temel ilkeleriyle bağdaşırlığı konusunda kapsamlı bilgi için bkz. ŞAHİN, s. 245-255.

39 SOYGÜT ARSLAN, Mualla Buket: Türk Ceza ve Ceza Usul Hukukunda Uzlașma Kurumu, Galatasaray Üniversitesi Yayınları, İstanbul 2008, s. 28-31. ŞAHİN, Cumhur/ GÖKTÜRK, Neslihan, Ceza Muhakemesi Hukuku -II-, Gözden geçirilmiş ve güncellenmiş 10. Bası, Seçkin Yayınevi, Ankara 2020, s. 212. (ŞAHIN/GÖKTÜRK -II).

Nitekim, ilgili madde gerekçesinde de bu husus açıkça ifade edilmiştir. Bkz. http://www2.tbmm.gov.tr/d22/1/1-0535.pdf (Erişim tarihi: 7/5/2019).

40 ÇKK md. 24: "Ceza Muhakemesi Kanununun uzlaşmaya ilişkin hükümleri suça sürüklenen çocuklar bakımından da uygulanır." 
aynı kurallara tâbi tutulmuştur. ${ }^{41}$

Uzlaştırma, hukuk sistemimizde soruşturma ve kovuşturulması şikâyete bağlı suçlar ile şikâyete tâbi olup olmadığına bakılmaksızın hafif olarak nitelendirilebilecek suçlar için kabul edilmiştir. CMK'nin 253/3. maddesindeki "soruşturulması ve kovuşturulması şikâyete bağlı olsa bile, etkin pişmanlık hükümlerine yer verilen suçlar yönünden uzlaştırma yoluna gidilemeyeceği” kuralı 2 Aralık 2016 tarihinde 6763 sayılı Kanun ile yapılan değişiklikle kaldırılmıştır. ${ }^{42}$ K1sacası, etkin pişmanlık hükümlerine yer verilen suçlar bakımından da uzlaştırma kurumunun uygulanmasının önünde artık hukuki engel kalmamıştır. ${ }^{43}$ Bir diğer anlatımla "cinsel suçlar hariç olmak üzere" şikâyete bağlı tüm suçlar yönünden -etkin pişmanlık hükümlerine yer verilmiş olsa bile- uzlaştırma kurumunun uygulanması hukuken mümkün olarak gözükebilir. Ancak, icra suçlarının kendine özgü niteliği gözetilerek bu konunun ayrıca irdelenmesi önem taşımaktadır. Öte yandan, uzlaştırma kapsamına giren bir suçun, bu kapsama girmeyen bir başka suçla birlikte aynı mağdura karşı işlenmiş olması hâlinde de uzlaştırma hükümleri uygulanmayacaktır. (CMK md. 253/3).

CMK'nin 253/3. maddesinin ilk cümlesini, ayn1 maddenin (1-a) fıkrasındaki "Soruşturulması ve kovuşturulması şikâyete bağlı suçlarda, şüpheli ile mağdur veya suçtan zarar gören gerçek veya özel hukuk tüzel kişisinin uzlaştırılması girişiminde bulunulur" anlamındaki hükümle birlikte

${ }^{41}$ Bu değişiklik neticesinde, suça sürüklenen çocuklarla ilgili olarak uzlaştırmanın kapsamının daraltıldığını; oysa, uzlaştırmanın amaçları dikkate alındığında, suça sürüklenen çocuklar bakımından uzlaştırmanın özellik gösteren yönlerinin ayrı düzenlemesi, kapsamının daha geniş tutulmasının yararlı olacağı konusunda ayrıca bkz. ÖZBEK, M.S., s. 159.

42 Bkz. RG. 2/12/2016, 29906.

Uzlaştırma kurumunu düzenleyen CMK'nin 253 ve 254. maddeleri 6/12/2006/ 5560, 26/6/2009/ 5918 ve 24/11/2016/ 6763 tarih ve sayılı Kanunlarla üç ayrı değişikliğe uğramıştır. Ceza Adalet Sistemimizde uzlaştırma kurumunun kabulü ve gelişim süreci hakkında ayrıca bkz. ÇETINTTÜRK, s. 420-433.

436763 sayılı Kanuna ilişkin madde gerekçesinde şu ifadeye yer verilmiştir:

"Madde ile, çağdaş ceza adaleti sistemlerinde en etkili onarıcı adalet uygulamalarından biri olarak kabul edilen uzlaşma, on yıllık uygulama sonuçları dikkate alınarak yeniden düzenlenmekte, kapsam ve yöntemi bakımından önemli değişiklikler getirilmektedir.

Soruşturulması ve kovuşturulması şikâyete bağlı suçların yanı sıra şikâyete bağlı olup olmadığına bakılmaksızın uzlaştırma yoluna gidilebilecek suçların sayısının artırılması ve etkin pişmanlık hükümlerine yer verilen suçlara ilişkin sınırlamanın kaldırılması suretiyle uzlaştırma kurumunun uygulanma alanı genişletilmektedir."

Gerekçe için bkz. https://mevzuat.tbmm.gov.tr/mevzuat/faces/kanunmaddeleri?pkanunlarn o=204725\&pkanunnumarasi $=6763$ (Erişim tarihi: 9/5/2019). 
İcra ve İflas Kanununun On Altıncı Babındaki Takibi Şikayete Bağlı Suçlarda...

değerlendirmek gereklidir. Anılan norm(özetle); "takibi şikâyete bağlı suçlarda uzlaştırma kurumu uygulanabilir" ilkesini açıkça ortaya koymaktadır. Söz edilen bu iki normdan hareketle; IIIK'nin on altıncı babındaki takibi şikâyete bağlı suçlarda da uzlaştırma kurumuna başvurulmalıdır" düşüncesi "maddenin lafzi yorumundan yola çıkarak" akla gelebilecektir. Ceza muhakemesi hukuku alanına ait uzlaştırma kurumunun icra ceza muhakemesi ile bağdaşıp bağdaşmadiğı konusunun irdelenmesiyle sorunun cevabı açı ve net olarak ortaya konulabilecektir.

İncelememizde öncelikle icra ceza muhakemesinin niteliği irdelenecek, sonrasında İIK' nin on altıncı babındaki takibi şikâyete bağlı suçlar genel olarak hatırlanarak; İIK'nin benimsediği dava ve cezanın düşmesi sisteminin hukuki niteliği ve bu fiiller yönünden uzlaştırma hükümlerinin uygulanabilirliği konusu değerlendirmeye açılacaktır.

\section{2. İCRA CEZA MUHAKEMESI}

\section{1. İcra Ceza Mahkemelerinin Kuruluşu ve Görevi}

Genel ceza yargılaması makamları, olay mahkemeleri anlamında asliye ceza ve ağır ceza mahkemeleridir. Bunların yanında adlî mahkemeler içinde yer almakla beraber yetkileri madde yönünden belirlenen özel olan ceza yargılaması makamları da (mahkemeleri) bulunmaktadır: Yüce divan, anayasa mahkemesi, trafik mahkemeleri ve icra mahkemeleri gibi. ${ }^{44} 5235$ sayılı Adlî Yargı İlk Derece Mahkemeleri ile Bölge Adliye Mahkemelerinin Kuruluş, Görev ve Yetkileri Hakkında Kanun'a göre; ceza mahkemeleri, asliye ceza ve ağır ceza mahkemeleri ile özel kanunlarla kurulan diğer ceza mahkemeleridir (md. 8). ${ }^{45}$ Belirtilen norm çerçevesinde icra ceza mahkemesi "özel kanunlarla kurulmuş ceza mahkemesi” niteliğindedir.

İcra mahkemeleri İIK'nin 4. maddesine göre kurulmuş olup; "İcra ve iflâs dairelerinin muamelelerine karşı yapılan şikâyetlerle itirazların incelenmesi icra mahkemesi hâkimi yahut kanun gereğince bu görev kendisine verilmiş olan hâkim tarafindan yapılır" (İ̈K md. 4-ilk cümle). Yine İİK'nin 346/3. maddesine göre; "Bu bapta (on altıncı bap) yer alan suçlarla ilgili davalara, icra mahkemesinde bakılır." Söz ettiğimiz normlardan hareketle icra mahkemeleri İIK'nin on altıncı babında düzenlenip adli para ve/veya hapis cezasını gerektiren suçlarda ve bu Kanuna göre disiplin ve tazyik hapsini gerektiren

\footnotetext{
44 KUNTER/ YENISEY/ NUHOĞLU, s. 519-529. Ayrıca bkz. CENTEL/ZAFER, s. 591-592.

45 Bkz. RG. 7/10/2004/ 25606.
} 
fiillerde icra ceza mahkemesi sifatıyla muhakeme yürütmektedir.

İcra mahkemesi, icra suçlarında yargılama makamıdır (İ̈K md. 348). Mahkeme gibi ceza verdiğinden, hâkimlik makamı olmayıp; mahkeme makamıdır ve ceza işlerinde ceza mahkemeleri gibi yetkilidir. ${ }^{46}$

\section{2. İcra Ceza Mahkemesinde Uygulanan Muhakeme Usulü}

Özel kanunla kurulmuş diğer ceza mahkemesi statüsündeki icra ceza mahkemesinde özel bir muhakeme usulü uygulanmaktadır. ${ }^{47} \mathrm{Bu}$ farkl1lık, icra ve iflas hukukunun amaçları ile icra suçlarının yöneldiği gaye ve niteliklerden kaynaklanmaktadır. İIK'nin icra ceza rejimini (mülga) Ceza Muhakemesi Usulü Kanunu (CMUK) 'nun 344. maddesinde yer verilmiş olan ${ }^{48}$ bir çeşit şahsi dava sistemine benzettiği de ileri sürülmektedir. ${ }^{49}$ Şahsi dava kurumu

46 KUNTER/ YENISEY/ NUHOĞLU, s. 525-526.

47 İcra mahkemesince yürütülen ceza muhakemesinin “özel ceza muhakemesi” olarak adland1rılmasına dair bkz. ÖZTÜRK, Bahri/ TEZCAN, Durmuș/ ERDEM, Mustafa Ruhan/ SIRMA GEZER, Özge/ SAYGILAR KIRIT, Yasemin F./ ALAN AKCAN, Esra/ ÖZAYDIN, Özdem/ ERDEN TÜTÜNCÜ, Efser/ ALTINOK VILLEMIN, Derya/ TOK, Mehmet Can: Nazari ve Uygulamalı Ceza Muhakemesi Hukuku, Güncellenmiş 12. Baskı, Seçkin Yayınevi, Ankara 2018, s. 824.

48 “Suçun Şahsi Dava Açmakla Takibi Halleri” Başl1klı CMUK'nin 344. maddesi:

“Aşağıda yazılı hallerde önce Cumhuriyet Müddeiumumisinin iştirakini tahrike hacet olmaksızın zarar gören kimse şahsi dava açmak suretiyle suçu doğrudan doğruya takip edebilir:

1 - Ceza Kanununun 191 inci maddesinin son fikrasinda yazılı tehdit.

2 - Ceza Kanununun 193 üncü maddesinin birinci fikrasında yazılı haneye taarruz.

3 - Ceza Kanununun 195 ve 197 nci maddelerinde yazılı gayrın sırrını ifşa.

4 - Ceza Kanununun 456 ncı maddesinin son fikrasinda ve 459 uncu maddesinin bir numarasında yazılı müessir fiiller.

5 - (Değişik bent: 11/05/1988 - 3445/16. md.) Ceza Kanununun 480 ve 482 nci maddelerinde yazılı hakaret ve sövme, (şu kadar ki, bu suçlar Ceza Kanununun 164 ve 166 ncı maddelerinde yazılı mahiyette olursa veya neşir yoluyla veya radyo ve televizyon veya benzeri kitle haberleşme araçlarıyla işlenmişse usulüne göre Cumhuriyet savcıları tarafindan takip olunur.)

6- Ceza Kanununun $516 \mathrm{nc}$ maddesinin birinci fikrasında ve 518 inci maddesinde yazıl1 izrar ve tahrip.

7- Ticaret Kanununun 64 ve 65 inci maddelerinde yazılı gayrı kanuni rekabet.

8- Hususi nizamlar ve kanunlarda yazılı edebi ve sınai mülkiyetlere ve güzel sanatlar mülkiyetine mütaallik suçlar.

Mağdur olan kimsenin kanuni mümessili varsa şahsi dava açmak ona aittir.

Mağdur bir cemiyet veya şirket olupta hukuk işlerinde bu sıfatla dava açmak ehliyetini haiz ise dava salahiyeti bu cemiyet veya şirketi temsil edenler tarafindan kullanılır."

49 POSTACIOĞLU, İlhan E./ ALTAY, Sümer: İcra Hukuku Esasları, Güncelleştirilmiş, Ge- 
CMK'nin yürürlüğe girişiyle kaldırılınca, İIK'de suç sayılan fiillerin otomatik olarak kamu davasına dönüşmüş olduğu da ifade edilmiştir. ${ }^{50}$ Öte yandan şahsi dava usulü 1 Haziran 2005 tarihinden beri uygulanmamakla birlikte İIK'de düzenlenen fiillere şahsi dava uygulamasına izin verilen suçlar arasında (mülga) CMUK'nin 344. maddesinde zaten yer verilmemiş olduğu da gözden kaçırılmamalıdır. Bilindiği üzere, şahsi dava, şikâyet, izin ve talep şartı gibi istisnalar resen araştırma mecburiyeti ilkesi ile kamu davasının mecburiliği ilkesinin istisnalarını oluşturmaktadır. ${ }^{51}$ İ̈K sistemi, ceza davasının açılması bakımından şahsi dava uygulamasına benzetilebilir ancak icra ceza muhakemesinin morfolojisinin ceza muhakemesine nazaran esasli farklılıklar içerdiğini de önemle belirtmek durumundayı.

İIK'nin "cezai hükümler" başlıklı on altıncı babında, suç olarak tanımlanan fiiller yanında izlenecek muhakeme hukukuna ilişkin kurallara da yer verilmiştir. Görev ve birleştirme yasağ 1 (md. 346), şikâyet süresi (md. 347), yetki (md. 348), yargilama usulü (md. 349), duruşma (md. 350), tahkikat (md. 351), karar (md. 352), itiraz (md. 353), davanın ve cezanın düşmesi ile ceza verilemeyecek hallere ilişkin norm (md. 354) icra ceza mahkemelerinde uygulanacak temel muhakeme kurallarıdır. İIK'de yer verilen ve göreve ilişkin normdan başlayarak dava ve cezanın düşmesine değin icra ceza mahkemesince izlenecek muhakeme hukuku kurallarını özel olarak düzenleyen kurallar bütününden oluşan muhakeme dalını "icra ceza muhakemesi" olarak

nişletilmiş 5. Bası, Vedat Kitapçılık, İstanbul 2010, s. 900.

50 Anılan düşünce için ayrıca bkz. ÖZTÜRK/ TEZCAN/ ERDEM/ SIRMA GEZER/ SAYGILAR KIRIT/ALAN AKCAN/ÖZAYDIN/ ERDEN TÜTÜNCÜ/ ALTINOK VILLEMIN/ TOK, s. 824, dipnot 51.

Bu görüşe dayanak olarak ise, 5320 sayılı CMK'nin Yürürlük Kanunu'nun 9. maddesi gösterilmektedir.

5320 sayll Kanun Madde 9:

Şahsî dava

Madde 9- (1) Özel kanunlarda öngörülen şahsî davalar kamu davasına dönüşür. (2) Hâlen şahsî dava usulüne göre yürütülen davalar da kamu davası olarak sürdürülür.

(3) Şahsî davacılar, katılan sıfatını alırlar.

(4) Bu davalar hakkında, 26.9.2004 tarihli ve 5237 sayılı Türk Ceza Kanunu ile Ceza Muhakemesi Kanununun uzlaşmaya ilişkin hükümleri uygulanır.

51 KUNTER/ YENISEY/ NUHOĞLU, s. 34-35.

Bir düşünceye göre, (mülga) CMUK'nin 344. maddesinde düzenlenen şahsi dava ile şikâyet ayrı şeylerdir. Bkz.

KUNTER/ YENISEY/ NUHOĞLU, s. 668. 
adlandıracağız. ${ }^{52}$ Çalışmamızın konusu itibariyle bu muhakeme dalını sadece takibi şikâyete bă̆lı suçlara ilişkin kuralları yönünden irdeleyeceğiz.

İcra ceza muhakemesinin tamamen kendine özgü muhakeme kuralları benimsemiş oluşu dikkat çekicidir. Bu bağlamda, İİK'nin yargılama usulüne ilişkin 349. maddesinin birinci fikrasının anayasaya aykırılığg somut norm denetimi yoluyla Anayasa Mahkemesi (AYM) önüne götürülmüştür. AYM, söz edilen normun iptali istemini şu gerekçelerle (yerinde olarak) reddetmiştir:

“Anayasa Mahkemesi'nin eşitlik ilkesi ile ilgili olarak verdiği birçok kararda belirtildiği üzere, aynı durumda olanlara aynı kuralların uygulanması halinde eşitlik ilkesine aykırılıktan söz edilemez. Ícra ve Iflas Kanunu'nda belirtilen suçları işleyenler ile başka yasalarda belirtilen suçları işleyenler eylemlerinin farklılı̆̆ nedeniyle aynı durumda değildirler. Bundan dolayı yasa koyucunun İcra ve Iflas Kanunu'nda bazı suçlar için farklı usul getirmesi, Anayasa'nın eşitlik ilkesine aykırılık oluşturmaz.

Öte yandan, itiraz konusu kural ile dilekçeyi alan mahkemenin duruşma için hemen gün tayin edip şikâyetçinin imzasını alması, sanı̆̆a celpname göndermesi ve tanık gösterilmiş ise onun da mahkemeye getirilmesi yasa koyucunun takdirinde olan usul kuralları olup Anayasa'ya aykırı bir yönü bulunmamaktadır." 53

\subsection{1. İcra Ceza Muhakemesinde Dava Açma Usulü}

İIK'nin "Yargılama usulü" başl1kl1 349/1. maddesine göre; şikâyet dilekçe ile veya şifahî beyanla yapılmakta, dilekçeyi veya dava beyanını alan icra mahkemesi duruşma için hemen bir gün tayin edip, şikâyetçinin imzasını alıp sanığa celpname göndermektedir. Şikâyet dilekçesi veya dava beyanının verilmesiyle doğrudan kovuşturma evresi başlatılmaktadır. İcra ceza muhakemesinde takibi şikâyete bağlı suçlar yönünden ceza davasının (kovuşturmasının) kamusallığ 1 yerine ceza kovuşturmasının kişiselliği ilkesi ${ }^{54}$ benimsenmiştir.

52 CGK, İİK'de öngörülen şikâyete bağlı suçlar açısından kendine özgü muhakeme usulü benimsendiği görüşündedir. Bkz. CGK 1/2/2011, 2010/16 HD-226, 2011/10. (UYAP). CGK ile aynı yönde ayrıca bkz. ERMENEK, s. 301.

Bir düşünceye göre ise, icra ve iflas suçları, icra ve iflas hukuku ile ceza hukukunun kesiştiği bir sahada bulunan; bu sebeple hem icra ve iflas hukuku hem de ceza hukukuna ilişkin bazı kuralların uygulanma alanı bulduğu bir daldır. Bkz. YILDIZ, s. 218.

53 AYM'nin 28/2/2008 tarihli ve 2006/71, 2008/69 say1lı kararı için bkz. RG. 16/4/2008, 26849.

54 Anılan ilkeler için ayrıca bkz. CENTEL/ZAFER, s. 519-523. 
İcra ceza mahkemesinin takibi şikâyete bağl1 suçlar yönünden yürüttüğü muhakemede şikâyet dilekçesi dava açan belge niteliğindedir. Anılan muhakemede bir soruşturma evresi bulunmadığ gibi duruşmada veya öncesinde Cumhuriyet savcısı da bulunmamaktadır. ${ }^{55}$ İcra ceza mahkemesince savcılık makamına sadece mahkeme kararı bildirilmekte ve böylelikle kanun yoluna başvurabilmesine imkân tanınmaktadır (İ̈K md. 350/2, 352/1).

Şikâyet dilekçesi veya dava beyanını alan icra mahkemesinin hemen duruşma için bir gün belirlemesi, şikâyet dilekçesi üzerine derhal kovuşturma evresinin başlaması anlamındadır. İcra ceza muhakemesinde "dilekçeyle ceza davası açılması" şeklinde (adeta ceza muhakemesi hukuku kurallarının ötesinde) bir durum söz konusu olup; bu özellik bir anlamda medeni muhakemeyi anımsatmaktadır. Şöyle ki, şikâyet dilekçesi ile açılması gereken dava, hatalı biçimde iddianame ile açılmış bile olsa; bu durum davayı kamu davası haline dönüştürmeyecektir. ${ }^{56}$

İİK'nin on altıncı babındaki takibi şikâyete bağlı suçlar yönünden şikâyette bulunulmuş olmasının bir muhakeme şartı olduğu kuşkusuzdur. Ancak, belirtilen suçlar yönünden şikâyetin gerçekleşmiş olması "sadece kovuşturma yapılması bakımından" bir muhakeme engelidir. Zira, bu suçlar yönünden şikâyet dilekçesinin icra ceza mahkemesine verilmesiyle doğrudan kovuşturma evresi başlamaktadır (İ̈K md. 349/1). Önemle vurgulayalım ki, icra ceza muhakemesi dava açılma usulü bakımından ceza muhakemesinden bariz şekilde farklılaşmakta; "şikâyet dilekçesiyle ceza davası açılması" biçiminde Ceza Adalet Sistemimizde başka örneği bulunmayan bir uygulama karşımıza çıkmaktadır.

\subsection{2. İcra Ceza Muhakemesinin Yürüyüşü}

Şikâyet dilekçesini veya dava beyanını alan icra mahkemesi duruşma için hemen bir gün tayin edip; şikâyetçinin imzasını alıp sanı̆̆a celpname

55 İIK' 'nin on altıncı babında resen kovuşturulan icra suçlarına da (İ̈K md. 333, 335, 336, 337, 342 ve 345/b) yer verilmiş olup, bu fiillerin soruşturması Cumhuriyet savcısı tarafindan yürütülmekte olup, bu konuda ayrıca bkz. aşağıda Bölüm 3. Aynı yönde ayrıca bkz. ERMENEK, s. 299-300.

56 CGK’ye göre; “...Şikâyete tabi olduğu belirtilen bu suçlarla ilgili olarak, şikâyetin doğrudan icra ceza mahkemesine yapılması gerektiğinden, 5271 sayılı Yasanın 170. maddesi uyarınca iddianame düzenlenmesine gerek bulunmadığı gibi, anılan Yasanın 170. ve devamı madde hükümlerinin de bu suçlar yönünden uygulanmasına olanak bulunmamaktadır." Bkz. CGK 13/2/2007, 2007/17, 28 sayılı kararı (UYAP).

Aynı yönde bkz. KÜRTÜL, Mehmet: Açıklamalı - Örnekli - İçtihatı İcra ve İflas Suçları, Gökçe Ofset Matbaacılık, Ankara 2012, s. 494. 
göndererek, kovuşturma evresini ve muhakemeyi başlatmaktadır. İcra ceza mahkemesi, tarafların bizzat hazır bulunmasını emredebileceği gibi muhakemeyi sanığın gıyabında da görebilmektedir. Öte yandan, şikâyetçi belirlenen zamanda gelmez ve vekil de göndermezse şikâyet hakkı düşmektedir (İIK md. 349/6).

İcra ceza muhakemesi tipik bir ceza muhakemesi niteliği taşımamakta olup, her iki muhakeme türü bakımından ortaya çıkan önemli farklara değinelim.

- Savunma hakkı bakımından: İcra ceza muhakemesinde sanığın savunmasının alınması zorunluluğu yoktur; savunma alınmaksızın ${ }^{57}$ dahi hapis cezasına hükmolunabilmektedir. Bunun için sanığa sadece usulüne uygun bir celpname çıkarılmış olması yeterlidir (İKK md. 349/1,5). ${ }^{58}$

57 Sanığa gönderilecek davetiyenin ihtarlı (meşruhatlı) olması ile "duruşmaya gelmediği takdirde yargılamanın yokluğunda yapılacağı” hususunun (mülga) CMUK'nin 225. maddesine uygun olarak bu davetiyede belirtilmiş olması gerektiğine ilişkin bkz. UYAR, Talih: İcra ve İflas Hukukunda Suç Sayılan Fiiller (İcra-İflas Suçları), Şafak Basım ve Yayınevi, Manisa 1987, s. 477.

CMUK'nin 225. maddesi, sanık gelmese bile duruşma yapılabilecek halleri; "tahkikatın mevzuu olan suçun gerek yalnız ve gerek birlikte olarak para cezasını, hafif hapis ve müsadere cezalarını gerektirmesi” hali ile sınırlandırmıştır. Bilindiği üzere, mülga TCK ve CMUK' de yer verilen "hafif hapis cezası" artık sistemimizde mevcut değildir. Buradan hareketle, CMK'nin 195. maddesi ise bu durumu; "suçun, yalnız veya birlikte adlî para cezasını veya müsadereyi gerektirmesi” durumu ile sınırlandırarak savunma hakkı güvencesinin kapsamını genişletmiştir.

58 İ̈K'nin 349. maddesinin beşinci fikrasının son tümcesi olan "Bu suretle de bulundurulamazsa muhakeme gıyabında görülür" biçimindeki kuralın da Anayasa'ya aykırı olduğu ileri sürülmüştür. AYM kararına göre iptal istemi şu gerekçeyle reddolunmuştur:

“...İcra ve Iflas Kanunu'nun 349. maddesinde, şikâyetçi ile sanığın mahkeme tarafindan belirlenen gün ve saatte mahkemeye gelmek veya vekil göndermek zorunda olduklarl, hâkimin gerektiğinde tarafların bizzat hazır olmasını isteyebileceği, saniğın başka yerde ikamet etmesi durumunda istinabe yoluyla sorguya çekileceği, sanığın, şikâyeti alanın veya istinabe edilenin hâkim huzuruna gelmemesi veya müdafi göndermemesi durumunda ve gerekli görülmesi halinde zabıta aracıllı̆̆ ile getirileceği belirtilmiştir.

Anayasa'nın 36. maddesinin birinci fikrasında herkesin meşru vasıta ve yollardan faydalanmak suretiyle yargı mercileri önünde davacı veya davalı olarak iddia ve savunma ile adil yargılanma hakkına sahip olduğu vurgulanmıştır.

Savunma hakkı adil yargılanmanın esaslı unsurlarındandır. Yargının temel görevi ve yargllama süreci sonucunda beklenen sonuç adaletin sağlanmasıdır. Bu sonuç, haklı ve haksızın ayırt edilmesi, sakat ișlemin ortadan kaldırılması, uğranılan zararın giderimi veya sanığın cezalandırılması şekillerinde ortaya çıkabilir. Usulüne uygun biçimde yapılan tebligata karşın, kendini savunmak için mahkemeye gelmeyen kişinin savunma hakkından vazgeçtiğinin kabulü gerekeceği gibi, duruşmaya fiilen gelmemek suretiyle yargılamanın devamının ve beklenen adalet ve yargısal sonucun elde edilmesine mani olunmamast gerektiği de hukuk 
Gerçekten, İIK'nin 349/5. maddesindeki “sanığın duruşmaya bizzat gelmediği veya müdafi göndermediği durumlarda bizzat bulunmasına lüzum görülürse zabıta marifetiyle getirileceği" normunun karşıt kavramından "icra ceza muhakemesinde sanığın savunması alınmadan da hüküm kurulabileceğine cevaz verildiği ortaya çıkmaktadır. Yine aynı maddenin yedinci fikrasındaki “... borçlunun (icra ceza muhakemesi bakımından sanığın) gıyabında verilen karara karşı eski hale getirme talebi” ibaresi de aynı düşünceyi teyid etmektedir. İIK'nin on altıncı babındaki hem takibi şikayete tâbi suçlar hem de resen takip edilen suçlar bakımından aynı ilke geçerlidir.

- Resen araştırma ilkesi bakımından: Ceza muhakemesindeki resen araştırma ilkesi icra ceza muhakemesinde geçerli değildir. İIK'nin “tahkikat usulü" başlıklı 351. maddesine göre; "Şikayetçi dilekçe veya beyanında gösterilmiş olduğu delillerle bağlıdır. Maznun müdafaası için tahkikatın tevsiini ancak bir kere isteyebilir." ${ }^{59}$ Ancak, bu hükümlere uyulmayıp, icra hâkiminin tıpkı bir ceza hâkimi gibi hareket ederek sanığın ve müştekinin gösterdiği, ayrıca kendisinin toplanmasına gerek gördüğü bütün delilleri toplayarak, tanık dinleyerek, bilirkişi incelemesi yaptırdığı ve Yargıtayın da mahkemeden delilleri toplamasını istediği gerekçesiyle uygulama eleştirilmektedir. ${ }^{60}$

devleti ilkelerindendir.

İtiraz konusu kural, yargılamanın sanığın gıyabında görülmesini çeşitli koşullara bağlamıştır. Öncelikle, sanığa celpname gönderilmesi, tanık gösterilmiş ise onun da mahkemeye getirilmesi gerekmektedir. Yasa her iki tarafin da belirlenen gün ve saatte mahkemeye gelmelerini zorunlu tutmuş, İcra Mahkemesine tarafların vekil aractlı̆̆ ile değil, bizzat hazır bulunmalarını da isteyebilme yetkisi vermiş, sanığın başka bir yerde ikamet etmesi halinde de istinabe yolu ile sorguya çekilmesini öngörmüştür. Sanık bildirimlere karşın icra mahkemesinin huzuruna gelmez veya müdafi göndermez ise mahkeme zabita aracıliğ ile de sanığ getirtebilecektir. Yargılamanın sanığın yokluğunda görülmesi tüm bu aşamalardan geçildikten sonra gerçekleştirilebilecektir. Sanığın usulüne uygun olarak yapılan bildirimlere karşın mahkemeye gelmemesi veya avukat göndermemesi, duruşmada hazır bulunma hakkından vazgeçtiği anlamına gelir. Bu nedenle, itiraz konusu kural Anayasa'ya aykırı görülmemiştir."

AYM'nin 28/2/2008 tarihli ve 2006/71, 2008/69 say1l kararı için bkz. RG. 16/4/2008, 26849.

59 İcra işlerinde sürat esas olduğu için, İIK'nin 351. maddesindeki şikâyet dilekçe veya beyanındaki delillerle bağlılık ve tahkikatın genişletilmesinin ancak bir defa istenebileceği ilkesinin benimsendiğine ilişkin ayrıca bkz. UYAR, s. 479.

60 Bkz. ÇOLAK, Haluk: İcra ve İflas Suçlarlisepile kacılar Dergisi, Sa. 53, İstanbul 2005, s. 90.

Konuyla ilgili bir kararında CGK şöyle içtihat etmiştir:

“...Şikâyet dilekçesinde kanıt olarak gösterilen icra takip dosyasının numarasının veya icra müdürlüğünün isminin veya bir yerde kurulmuş bulunan icra müdürlüklerinin numaras1nın hatalı bildirilmiş olması halinde, bu hatanın giderilmesine yönelik olarak asıl icra takip 
- Yetki kuralı bakımından: İcra ceza mahkemesinin tâbi olduğu (yer yönünden) yetki kuralı, ceza muhakemesi hukukunun genel ilkesi olan "suçun işlendiği yer" olmayıp; "icra takibinin yapıldığı yer" olarak kabul edilmiştir (İ̈K md. 348).

- Davaların birleştirilmesi bakımından: İcra ceza mahkemesinin görevindeki suçlara ilişkin davalar, diğer mahkemelerde görülen ceza davaları ile birleştirilemez (İK md. 346). Hâlbuki ceza muhakemesi hukukunda bağlantılı davaların birleştirilmesi mümkündür.

- Muhakeme süresi bakımından: İcra mahkemesi iki tarafın ifadelerini ve bütün delillerini ve iddia ve müdafaalarını dinledikten sonra nihayet beş gün içinde kararını verir (İ̈K md. 352/1).${ }^{61}$ Ceza muhakemesinde yargılamanın tek celsede bitirilmesi ancak "ideal bir temenni" olarak teoride savunulmakta ise de ${ }^{62}$ İIK'nin anılan kuralına benzer başka bir norm mevzuatımızda yer almamaktadır.

Özetle, icra ceza muhakemesinin yöneldiği amaçlar itibariyle seri bir muhakeme usulü inşa ettiği ve bu yönüyle de "ceza muhakemesi hukukunun bazı temel ilkelerinden ayrıldığı" açıkça ortadadır.

\section{3. İcra Ceza Muhakemesinin Ceza Muhakemesi ile Karşılaştırılması}

İcra ceza muhakemesi bu alana dair normlardan da açıkça görüldüğü üzere tipik bir "suç muhakemesi" niteliğinde değildir. İcra ceza muhakemesi, takip sisteminin iyi işlemesini sağlama ile alacakların süratle ve kolaylıkla cebri icrası amacına yönelmiştir. Bu itibarla, icra hukukunun serilik ve basitlik ilkesinin icra ceza muhakemesine yansıdığ 1 görülmektedir. Kısacası, icra ceza muhakemesi, İIK'nin suç olarak tanımladığ fiillerin muhakemesini konu edinmiş; hem hukuk muhakemesi hem ceza muhakemesinden-bünyesine uygun düştüğü ölçüde- bazı kuralları adeta ödünç alarak yürütülen kendine

dosyası numarasının veya icra müdürlüğü adının veya numarasının bildirilmesi yeni delil bildirme kapsamında değerlendirilemez. Aksine, mutlaka araştırılarak açıklığa kavuşturulması gereken böyle bir durumda yerel mahkeme tarafindan, müşteki vekiline makul bir süre verilerek yargılama konusu yapılan asıl icra takip dosyasının bildirilmesi sağlanmalıdır." CGK 1/2/2011, 2010/16 HD-226, 2011/10 (UYAP).

${ }_{61}$ Uygulamada dava sayısının fazlalığı ve yazılan müzekkerelere geç cevap verilmesi nedeniyle mahkemelerin bu hükme uyamadıklarına dair bkz. ÇOLAK, s. 91.

${ }_{62}$ Bu konuda değerlendirme ve eleştiri için ayrıca bkz. ÖZTÜRK/ TEZCAN/ ERDEM/ SIRMA GEZER/ SAYGILAR KIRIT/ALAN AKCAN/ÖZAYDIN/ ERDEN TÜTÜNCÜ/ ALTINOK VILLEMIN/ TOK, s. 630. 
özgü nitelikte bir muhakeme dalıdır. ${ }^{63}$

İcra ceza muhakemesinde, soruşturma evresine dahi gerek duyulmaksızın; sadece alacaklının şikâyetiyle uyuşmazlı̆̆ın doğrudan icra ceza mahkemesi önüne getirilmesine cevaz verilmiştir. Burada, alacaklının şikâyeti üzerine yürütülen dava, borçlu aleyhine yürütülmüş ve kesinleşmiş olan bir icra takibine dayanmaktadır. $\mathrm{Bu}$ itibarla, icra ve iflas hukuku sisteminde kesinleşmiş icra takibinin süratle yerine getirilmesi amaç olup, bu gayeye yönelik olarak alacaklının alacağına kavuşması sürecini akamete uğratan bazı filler suç olarak tanımlanmıştır. Bu anlamda, kendine özgü şartları olan icra ceza muhakemesinde soruşturma evresine bile gerek duyulmamıştır.

İcra ceza muhakemesinin İIK'nin amacına yönelik özel nitelikte bir seri muhakeme hukuku kuralları bütünü olduğu söylenebilir: Hemen dava açılsın, şikâyetçi (alacaklı) davasını mutlaka takip etsin, delillerini sunsun, sanık (borçlu) duruşmaya gelmese dahi karar verilsin, verilen cezanın infaz aşamasında dahi ödeme veya şikâyetten vazgeçme ile düşmesine imkân tanınsın. Tüm bu ilkeler çerçevesinde alacaklının alacağına süratle kavuşması ile iyi işleyen bir takip sistemine dolaylsiyla piyasa mekanizmasına, millî ekonomiye sahip olunması hedefine katkı sağlanması amacı açıkça ortaya çıkmaktadır.

CMK, suç soruşturmasına ilişkin temel güvenceler benimseyen ve kaynağını hukukun temel ilkeleri ile Anayasa'dan alan bir temel kanun niteliğindedir. İIK'nin on altıncı babındaki takibi şikâyete bağlı fiiller yönünden CMK' deki güvencelerin suç faillerine (borçluya) sağlanması gerekli görülmeyerek bu suçlar yönünden daha az güvenceli ancak özel bir muhakeme sistemi benimsenmiştir. Kısacası, CMK'nin korumak istediği hukuki değerler, haklar ile İIK' nin güvence altına almak istedikleri temelden farklıdır. Ezcümle, icra ceza muhakemesinde ancak fiilin ve muhakemenin bünyesine uygun düştüğü ölçüde CMK hükümleri tatbik edilebilecek; CMK'deki her norm

${ }^{63}$ CGK'nin icra ceza muhakemesine bakışı ise şu şekildedir:

"İcra ve İflas Yasasında kendine özgü bir yargılama sistemi öngörülmüş olması, bu yasada düzenlenen suçlara ilişkin yapılan yargılama işlemlerinin ceza yargılaması faaliyeti olmad1$\breve{g}_{1}$ anlamına gelmemektedir. Bu yasada aksine kısıtlayıcı hüküm bulunmadığı hallerde ceza yargılamasının "usul kurallarının öngördüğü ilkeler doğrultusunda, somut gerçeğin her türlü kuşkudan uzak bir biçimde kesin olarak saptanması" amacı ve "adaletin tam olarak gerçekleşmesi için, öne sürülen ve olaya 1şık tutabilecek nitelikteki tüm yasal kanıtların araştırılıp tartışılması" zorunluluğu, İIY'da düzenlenen suçlara ilişsin yapılan yargılamalarda da aynen geçerlidir.” Bkz. CGK 1/2/2011, 2010/16 HD-226, 2011/10. (UYAP). 
İIK'deki fillere uygulanamayacaktır. ${ }^{64} \mathrm{Bu}$ anlamda ceza muhakemesi ile icra ve iflas hukuku dolayısıyla icra ceza muhakemesinin amaçları ve konusunun hiçbir şekilde gözden kaçırılmaması önem taşımaktadır.

\section{3. İCRA VE İFLAS KANUNUNUN ON ALTINCI BABINDA DÜZENLENEN FIIILLER}

\section{1. İcra ve İflas Kanununun On Altıncı Babında Düzenlenen Fiillerin Sınıflandırılması}

İIK'nin on altıncı babında ceza hukuku yaptırımına bağlanan fiillere yer verilmiştir. Anılan fiiller, "İ̈K'de suç olarak tanımlanan fiiller, İIK'ye aykırılık suçu, icra suçu" şeklinde farklı isimlerle adlandırılarak, ${ }^{65}$ çeşitli sınıflandırmalara tâbi tutulmaktadır.

Postacıoğlu ve Altay, İIK' deki "münferit icra suçları" olarak adlandırılan fiillerin, suç teşkil eden eyleme uygulanacak yaptırıma göre; a) Disiplin ve tazyik hapsi cezasını gerektiren suçlar, b) hapis ve adli para cezasını gerektiren suçlar olarak iki kategoriye ayrılması gerektiği düşüncesindedir. ${ }^{66}$

Yılmaz ise, 1) Cezai hükümler başlıklı "On altıncı Bap” hükümleri, 2) Taksiratlı ve hileli iflas ${ }^{67}$ başlı̆̆ını taşıyan "On üçüncü Bap" hükümleri, 3) Hapisle tazyik hükmü şeklinde bir tasnif yapmaktadır. ${ }^{68}$

Ermenek tarafından yapılan bir ayrıma göre; İK'nin on altıncı babında yer verilen fiillerin tamamı salt iflâs hukukuna ilişkin olmayıp; bazıları icra suçları ile beraber (örneğin, 331, 337, 337/a, 345 ve 345/b maddeler gibi), bazıları konkordatoya ilişkin suçlar ile beraber $(333,334$. maddeler gibi), bazıları ise salt iflas hukukunu ilgilendiren suçlar olarak düzenlenmiştir (336,

\footnotetext{
64 Aynı yönde olmak üzere, ceza muhakemesine ilișkin olarak özel Kanunlarda mevcut olan düzenlemelerin IIIK'deki fiiller yönünde öncelikle uygulanmaya devam edileceği; CMK'ye atıf yapılmamış diğer hükümlerinin ise, ilgili özel kanunun amaç ve prensiplerine uygun düştüğü ölçüde, kıyas yolu ile uygulanacağına dair ayrıca bkz. ERMENEK, s. 288.

${ }^{65}$ Krş. UYAR, s. 2-3.

66 Bkz. POSTACIOĞLU/ ALTAY, s. 902-914.

Benzer ayrımlar için bkz. SARI, s. 42 vd. UYSAL, Mehmet: "Yeni Yasaların Işı̆̆ında İcra ve İflas Suçları”, İstanbul Barosu Dergisi, Y11 2006, Cilt: 80, Sa. 3, s. 1014 vd.

67 Anılan fiillerin, 1 Haziran 2005 tarihinde yürürlüğe giren 5237 sayılı TCK'nin 161. maddesinde "hileli iflas" ve 162. maddesinde "taksirli iflas" biçiminde hem suç olarak tanımland1ğını hem de yaptırımlarının düzenlendiğini hatırlatmak isteriz.

68 YILMAZ, s. 497.
} 


\section{7, 345/a maddeler gibi ). ${ }^{69}$}

Muşul tarafindan savunulan ve CGK tarafindan benimsenen bir düşünceye göre ise, haksızlık içeren fiilin karşılığında öngörülen yaptırıma göre; İIK'nin on altıncı babındaki fiiller "icra suçu ve kabahati" şeklinde ikili bir ayrıma tâbi tutulmaktadır. ${ }^{70} \mathrm{Bu}$ düşünceye göre, karşılı̆̆ında disiplin ve tazyik hapsi gerektiren fiiller "icra kabahati" olarak; hapis ve/veya para cezasını gerektiren fiiller ise "icra suçu" olarak adlandırılabilecektir.

İIK'nin 346. maddesinin ilk fikrası; "Bu Kanun hükümlerine göre verilecek disiplin veya tazyik hapsinden.." üçüncü fikrası ise; "Bu bapta yer alan suçlarla ilgili davalardan..." söz ederek bu yaptırımlara icra mahkemesince karar verileceği/ bakılacağı kuralını getirmektedir. Bu kuraldan hareketle, icra ceza mahkemesinde muhakemesi yürütülecek fiillerin "İIK'nin on altınc1 babındaki suçlar" ile "İIK' deki disiplin veya tazyik hapsini gerektiren fiiller" olduğu ortadadır. İcra mahkemelerinin görevine ilişkin bu normla öngörülen ve "suç olarak tanımlanan" fiiller, TCK'nin benimsediği "suç: karşılığında hapis ve/veya adli para cezası öngörülen fiiller" sistemiyle uyumludur.

“İIK'de disiplin veya tazyik hapsi öngörülen fiillerin” TCK sistemi içindeki yeri irdelenmelidir. İIK'nin on altıncı babında tazyik hapsini gerektiren (338/2, 340, 341, 343 ve 344. maddeler) ve disiplin hapsini gerektiren (md. 339) fiillere de yer verilmiştir. Tazyik veya disiplin hapsini gerektiren bir fiilin TCK sisteminde "suç" olarak kabul edilemeyeceği kuşkusuzdur. Gerçekten, TCK'nin 45. maddesindeki temel ilkeye göre; suç karşılığında uygulanan yaptırım olarak cezalar, hapis ve adlî para cezalarıdır. Öte yandan, Kabahatler Kanunu (KK)'nun 2. maddesine göre, 'Kabahat deyiminden; kanunun, karşıllğında idarî yaptırım uygulanmasını öngördüğü haksızlık anlaş1lır." Bu emredici norm çerçevesinde bir fiilin kabahat olduğundan söz edebilmek için karşıllğında idari yaptırım öngörülmüş olması gereklidir. Disiplin hapsi ve (bunun bir şekli olan) tazyik hapsinin "disiplin yaptırımı" niteliğinde olduğu; ${ }^{71}$ ancak bununla hapis cezası yaptırımı arasında farklılıklar ve benzerlikler bulunduğu kuşkusuzdur. ${ }^{72}$ Dolayısıyla, İİK'nin öngördüğü

69 ERMENEK, s. 290.

70 CGK 25/4/2006, 2006/16.HD-123, 2006/127 (UYAP).

Muşul, icra suçlarını "suçlar ve kabahatler" şeklinde ikili bir ayrıma tâbi tutmaktadır. Bkz. MUŞUL, Timuçin: İcra ve İflas Hukuku, Cilt: II, Gözden geçirilmiş ve genişletilmiş 6 . Bask1, Adalet Yayınevi, Ankara 2013, s. 1843. (MUŞUL, 2013).

71 İcra mahkemesinin disiplin hapsi ve tazyik hapsine ilişsin kararlarını "adlî tedbir" olarak nitelendiren farklı bir düşünce için ayrıca bkz. ERMENEK, s. 309.

72 Disiplin hapsi ve tazyik hapsinin niteliği konusunda ayrıca bkz. ÖZGENÇ, İzzet: Türk 
disiplin ve tazyik hapsini hiçbir zaman "idari yaptırım" ve bu fiilleri de "icra kabahati" olarak nitelendirmek mümkün değildir. Bu itibarla, "icra kabahati - icra suçu” biçimindeki sınıflandırmanın kanuni temellerinin bulunmadĭ̆ düşüncesindeyiz.

İIK'nin disiplin hapsi, tazyik hapsi, adli para ve hapis cezası yaptırımlarına tâbi kıldığ fiillerle TCK ve Kabahatler Kanununun sistemi dışında kendine özgü bir yapı oluşturduğu söylenebilir. Ceza Adalet Sistemimizin temel ilkelerine uygun olarak -gerektirdikleri yaptırımların türü ile tâbi oldukları muhakeme usulüne göre- İIK'nin on altıncı babında yaptırıma bağlanan fiiller şu şekilde sınıflandırılabilir:

a) Tazyik hapsini gerektiren fiiller (İ̈K md. 338/2, 340, 341, 343 ve 344.). ${ }^{73}$

b) Disiplin hapsini gerektiren fiiller (İ̈K md. 339) ${ }^{74}$

c) Takibi şikâyete bağlı icra suçları (İ̈K md. 331, 332, 333/a, 334, 337/a, $338 / 1$ ve $345 / a)$,

d) Resen kovuşturulan icra suçları (İ̈K md. 333, 335, 336, 337, 342 ve $345 / b)$.

\section{2. İcra ve İflas Kanununun On Altıncı Babındaki Takibi Şikâyete Bağlı Suçlar}

İK'nin on altıncı babinda düzenlenen ve adli para cezası ve/veya hürriyeti bağlayıcı ceza gerektirip "takibi şikâyete bağlı olan icra suçları" şunlardır:

Ceza Kanunu Gazi Şerhi (Genel Hükümler), Üçüncü baskı, Adalet Bakanlığı yayını, Ankara 2006, s. 621-624.

73 İ̈K'nin 76. maddesinde yer verilen ve uygulamada sıklıkla karşılaşılan "mal beyanında bulunmayan borçlunun alacaklının talebi üzerine hapisle tazyik olunacağı" normu; konumuzun IIIK'nin on altınc babındaki takibi şikâyete bağlı fiiller oluşu itibariyle yaptığımız sinıflandırmaya dahil edilmediğini belirtmeliyiz

İIK'nin on altıncı babında tazyik hapsi yaptırımına bağlanan fiiller şunlardır: Nafakaya ilişkin kararlara uymayanlar hakkında üç aya (md. 334); hakikata muhalif beyanda bulunanlar hakkında bir yıla (md. 338/2); borçlunun ödeme şartını ihlali halinde üç aya (md. 340); çocuk teslimi emrine muhalefet edenler hakkında altı aya (md. 341); 30 ve 31 inci maddeler hükmüne muhalefet edenler hakkında üç aya (İ̈K md. 343) ve nihayet nafakaya ilişkin kararlara uymayanlar hakkında üç aya kadar tazyik hapsi (md. 344) uygulanabilecektir.

74 İK'de disiplin hapsi yaptırımına yer verilen tek fiil; beyandan sonra mal ve kazançta olan tezayüdü bildirmeyen

borçlu hakkında bir aya kadar disiplin hapsi yaptırımı uygulanabilmesidir (md. 339). 
İcra ve İflas Kanununun On Altıncı Babındaki Takibi Şikayete Bağlı Suçlarda...

a) Alacaklısını zarara sokmak kastıyla mevcudunu eksiltmek suçu (İ̈K md. $331)$

b) Aczine kendi fiiliyle sebebiyet vermek veya vaziyetinin fenalığını bilerek ağırlaştırmak suçu (İIK md. 332),

c) Alacaklısını zarara uğratma kastı ile ticari işletmede yöneticinin borçlarını ödememesi suçu (İ̈K md. 333/a),

d) Konkordatoda veya sermaye şirketleri ile kooperatiflerin uzlaşma yoluyla yeniden yapılandırılmasında yetkili kimseleri hataya düşürmek ya da konkordato veya uzlaşma yoluyla yeniden yapılandırma koşullarına uymamak suçu (İ̈K md. 334),

e) Ticareti terk hükümlerine aykırılık suçu (İIK md. 337/a),

f) Gerçeğe aykırı beyanda bulunmak suçu (İ̈K md. 338/1),

g) Sermaye şirketlerinin iflasını istememek suçu (İ̈K md. 345/a).

İIK'de tanımlanan bu fiillerin takibi şikâyete bağlı olup kanun koyucu "alacaklının şikâyeti üzerine, ilgilinin şikâyeti üzerine..." ve benzeri ifadelerle bu hususu belirtmiştir. Yukarıda sıralanan, İIK'nin on altıncı babında düzenlenen takibi şikâyete bağlı icra suçları (kısaca "icra suçu veya takibi şikâyete bağlı icra suçu” olarak adlandırılabilecek fiiller) Kanun'un 354. maddesindeki dava ve cezanın düşmesi sistemine tâbi olmaları sebebiyle çalışmamızın konusunu oluşturmaktadır.

İIK'deki resen takip edilen icra suçları ile disiplin veya tazyik hapsini gerektiren fiillerin ise, İIK'nin 354. maddesi kapsamında bulunmadığından incelememizin sınırları dışında kaldığını belirtmeliyiz.

\section{3. İcra ve İflas Kanununun On Altıncı Babındaki Takibi Şikâyete Bağlı Suçlarda Korunan Hukuki Yarar ve Diğer Suç Tipleriyle Karşılaştırılması}

Hukuk düzeninde, kanuni tipe uygun ve hukuka aykırı davranışlar "suç" olarak tanımlanarak ceza yaptırımına bağlanmaktadır. Bu anlamda, hukuk normunun bir değer hükmü oluşu nazara alındığında; ceza normu ile fiilin değerlendirmesi yapılarak, kişilerin davranışlarının doğru olmayıp "haksızlık teşkil ettiği”" tespit edilince, bu davranışa belirli hukuki sonuçlar 
uygulanmaktadır. ${ }^{75}$ Haksızlık olgusunun, içeriğine göre değerlendirilebilmesi mümkün olduğundan, azlığına veya çokluğuna göre, bazı fiiller suç; bazıları ise kabahat olarak tanımlanabilmektedir. ${ }^{76}$

Suçla korunan hukuki yarar veya bir başka ifadeyle suçun hukuki konusu; suç olarak tanımlanan ve ceza normu ile koruma altına alınan hukuki değeri ifade etmektedir. ${ }^{77}$ Hukuki değerlerin farklı önemde oldukları gözetildiğinde ceza hukuku bütün hukuki değerleri değil; sadece -son çare olarak- ceza yaptırımı ile korunması gereken değerleri korumaya almaktadır. ${ }^{78}$ Konusu cebri icra olan icra ve iflas hukukunda bazı hukuki değerlerin ceza hukuku araçlarıyla korunması düsüncesi diğer suçlara göre farklılık arz etmektedir.

Sağlıklı işleyen bir ekonomik sistemin varlığı, hem toplumsal hayatın devamı hem de ülke kalkınmasının sağlanması bakımından hayati önemdedir. Ekonomik hayat denilince sadece üretim, yatırım, satış ve tüketim faaliyetleri akla gelmemekte; tüm bunların finansmanı için alacakların ödenmesini sağlamak üzere iyi işleyen bir cebri icra hukuku sisteminin varlığı da zorunluluk arz etmektedir. Ekonominin önemli bir parçası olan icra hukukunun iyi işlemesinde devletin menfaati ve görevi vardır. ${ }^{79}$ Cebri icra, borçların devlet kuvveti (yardımı) ile zorla yerine getirilmesi olup; bu süreçte cebri icra organlarının alacaklı ile borçlu arasındaki menfaatler dengesini de gözetmesi gereklidir. ${ }^{80} \mathrm{Bu}$ anlamda, "icra suçu" olarak tanımlanan fiil "salt

75 HAFIZOĞULlARI, Zeki: Ceza Normu Normatif Bir Yapı Olarak Ceza Hukuku Düzeni, US-A Yayıncılık,

Ankara 1996, s. 127-128.

76 AKBUlUT, Berrin: Ceza Hukuku Genel Hükümler, Adalet Yayınevi, Ankara 2015, s. 170-171.

77 “Cezaî menfaat" kavramı, devletin, bizzat kendi emniyetini veya toplumun emniyetini suçların tehlikesine karşı himaye etmekteki menfaati bütün suç ipotezlerinde bulunmakla, ceza kanununun bahşettiği himayeyi karakterize etmektedir. Cezaî menfaat ve suçun hukuki konusuna dair ayrıca bkz. TOROSLU, Nevzat: Cürümlerin Tasnifi Bakımından Suçun Hukuki Konusu, Ankara Üniversitesi Hukuk Fakültesi Yayınları No. 273, Ankara 1970, s. $160-173$.

78 AKBULUT, s. 53.

79 SARI, s. 11.

${ }^{80}$ Doktrinde, İIK'nin 85/son maddesindeki "haczi koyan memur borçlu ile alacaklının menfaatlerini mümkün olduğu kadar telif etmekle (bağdaştırmakla, gözetmekle) mükelleftir" ilkesinin tüm icra ve iflas hukuku bakımından geçerli bir ilke olduğu yerinde olarak ifade edilmektedir. Ayrıca bkz. KURU, Baki: İcra ve İflas Hukuku Eı Kitabı, Tamamen yeniden yazılmış ve genişletilmiş ikinci baskı, Adalet Yayınevi , Ankara 2013, s. 47. 
borcu ödememek olmayıp; borçluların kötüniyetli davranışlarıdır." ${ }^{\text {"1 }}$ Cebri icra sisteminin iyi işlemesini engelleyecek bu tür davranışların önlenmesi gerektiği kuşkusuzdur. Bu noktada, korunan hukuki değerin önemi itibariyle -son çare olarak- ceza hukuku yaptırımları devreye alınarak IIIK' de bazı fiiller suç olarak tanımlanmıştır.

İIK'de yer verilen fiiller ekonomik suçlardan olup; cezai hükümler ile hem alacaklıların ve borçluların hem de tüm ekonomik düzenin korunmasina hizmet etmek suretiyle toplumsal menfaatlerin korunmas1 da amaçlanmaktadır. ${ }^{82}$ Belirtilen gayeye yönelik olmak üzere, icra takip sisteminin yürüyüşüne engel olarak görülen bazı davranışlara mani olmak ${ }^{83} \mathrm{ve}$ böylelikle sistemin iyi işlerliğini sağlamak üzere bazı fiiller "icra suçu” olarak tanımlanarak karşılığında yaptırımlar öngörülmüştür. İcra ve iflas suçlarının kabulündeki amaç; cebri icrayı daha etkili kılmak içindir. ${ }^{84}$ Ezcümle, icra suçlarında korunan hukuki yarar, kötüniyetli davranışları engellemek suretiyle cebri icra sisteminin etkin işlemesine ilişkin alacakllartn ve genis anlamda devletin çıkarlarının korunması şeklinde ortaya çıkmaktadır. İİK'de bazı fiillere cezaî bir sonuç bağlanmasında, cezalandırmanın genel gayesi olan suçlulukla mücadele, önleme ve failin topluma kazandırılmasından farklı olarak; "borçluyu borcun ifasına zorlamak gibi özel bir amacın bulunması" 85 icra suçlarının diğer suçlardan koruduğu hukuki değer bakımından farklılaştığı ilk nokta olarak dikkat çekmektedir. ${ }^{86}$

81 UYAR, s. 2-3.

İ̇K ile sözleşmeden borcun yerine getirilememesi değil; borçlunun kötüniyetli davranışlarının yaptırıma bağlandığ 1 ve bu sebeple anılan suçların Anayasa'nın 38. maddesindeki "Hiç kimse, yalnızca sözleşmeden doğan bir yükümlülüğü yerine getirememesinden dolayı özgürlüğünden alıkonulamaz" kuralına aykırılık oluşturmadığına dair kapsamlı bilgi için bkz. YILMAZ, Ejder: "Borçlunun Sözleşmeden Doğan Yükümlülüğünü Yerine Getirememesine İlişkin Anayasa Hükmü ve İcra ve İflâs Suçları”, Prof. Dr. Ergun Önen'e Armağan, Marmara Üniversitesi Hukuk Fakültesi, İstanbul 2003, s. 497.

Aynı konuda bkz. ERCAN, İbrahim: “İcra ve İflas Suçları Üzerine Bazı Düşünceler”, Selçuk Üniversitesi Hukuk Fakültesi Dergisi, 2005, C. 13, Sa. 1, s. 7-32.

82 MUŞUL, Timuçin: İflas Suçları Taksiratlı ve Hileli İflas Suçları ile Diğer İflas Suçları, Filiz Kitabevi, İstanbul 1998, s. 7, 33. (MUŞUL, 1998).

83 Krş. YILMAZ, s. 499.

${ }^{84}$ KURU, s. 49.

85 ERMENEK, s. 303.

86 IIIK'nin on altıncı babında yer verilen ve takibi şikâyete bağlı olan yedi ayrı suçun (md. 331, 332, 333/a, 334, 337/a, 338/1 ve 345/a) unsurları bakımından ayrı ayrı değerlendirilmesi ve bu bağlamda netice unsuru yönünde incelenerek şeklî (neticesiz/neticesi harekete bitişik) suç-maddi (neticesi hareketten ayrılabilen) suç ayrımı anlamında ele alınmasıı 
IIK'nin on altıncı babındaki takibi şikâyete bağlı suçlar yönünden "dava ve cezanın düşmesine ilişkin kendine özgü bir sistem" benimsenmesi ise, belirtilen suçların diğer bir farkı olarak ortaya çıkmaktadır. Hukuk düzeninde, bazı suçlar Cumhuriyet savcılığınca kamu adına - resen takip edilirken; bazıları ise suçtan zarar görenin şikâyetine bağlı kılınmıştır. Söz edilen ayrımın temelinde, suçla korunan hukuki değerin önemi, niteliği ve bu değerin ihlaliyle kimin doğrudan zarar gördüğü konularıyla birlikte suç politikası belirleyici etken olmaktadır. Kanun koyucu, icra ve iflâs hukuku alanında bazı şuçların takibini şikâyete tâbi kılmakla; borçlunun suç teşkil eden bir fiili nedeniyle alacakl ile borçlu arasında bozulan menfaat dengesinin tekrar kurulmasını amaçlamaktadır. ${ }^{87}$ Bir diğer yönüyle, suçla korunan hukuki yararın sahibi olarak alacaklının şikâyetiyle dış dünyaya yansıyan iradesine yani alacağın ödenmesine ayrı bir önem atfederek, "şikayetten vazgeçme veya borcun ifasını ceza davasında düşme sebebi olarak kabul etmektedir (IIIK md. 354/1). Gerçekten, müştekinin şikâyetinden vazgeçmesi veya borcun ödenmesi halinde, bozulan dengenin tekrar kurulduğu varsayılarak, İIK'nin 354. maddesindeki dava ve cezanın düşmesine ilişkin özel nitelikteki hüküm benimsenmiştir. ${ }^{88}$ Kısacası, cebri icra sisteminin iyi işlemesine ilişkin olarak devletin ve özelinde alacaklının çıkarlarını korumayı amaçlayan kanun koyucu, İIK'nin on altıncı babında bu gayeye yönelik olarak bazı fiilleri şikâyete bağlı suç olarak tanımlanıp, ceza hukukundaki suçlulukla mücadele ve önleme gayelerinden nispeten ayrılarak; borçluyu borcun ifasına zorlamak amacına öncelik verilmiştir. Nitekim, bu amaca yönelik olan şikayetten feragat veya ödeme halinde davanın ve cezanın bütün neticeleriyle düşeceğine ilişkin norm (İ̈K md. 354/1) borcun ödenmesi gayesine öncelik verildiğini açıkça ortaya koymaktadır.

\section{4. İCRA VE İFLAS KANUNUNDA DAVA VE CEZANIN DÜŞMESI SISTEMI}

İ̇'nin 354/1. maddesindeki dava ve cezanın düşmesi sistemine göre "düşme" kararı verilebilmesi için şu iki durumdan herhangi birinin gerçekleşmesi kâfi olup, bunlar;

çalışmamızın kapsamı ve sınırlarının ötesindedir. Ancak, konumuz itibariyle, söz edilen suçların hepsinde "cebri icranın amacına ulaşmasını engelleme amacına yönelmiş hareketlerin" suç olarak tanımlanarak, farklı neticelere ilgili suç tanımlarında yer verildiğini belirtelim. Anılan suç tiplerine dair ayrıca bkz. SARI, s. 76 vd.

87 ERMENEK, s. 303.

88 ERMENEK, s. 303-304.

Ankara Hacı Bayram Veli Üniversitesi Hukuk Fakültesi Dergisi C. XXIV, Y. 2020, Sa. 4639 
İcra ve İflas Kanununun On Altıncı Babındaki Takibi Şikayete Bağlı Suçlarda...

1) Takibi şikâyete bağlı olan suçta müştekinin şikâyetinden feragati veya

2) Borcun ödendiğinin sabit olmasıdır.

İIK'nin 354/1. maddesiyle basit, yalın bir dava ve cezanın düşmesi sistemini benimsenmiştir. Buna göre dava ve cezanın düşmesi için; borcun ödendiği sabit olacak veya müşteki şikâyetinden feragat edecektir.

\subsection{Dava ve Cezanın Düşmesi Sisteminin Hukuki Niteliği}

CGK'nin 2005 tarihli içtihadından ${ }^{89}$ hareket eden Yargıtay özel daireleri, İİ'nin 354/1. maddesindeki sistemin hukuki niteliği konusunda değerlendirme yapmaksızın, bu normu "uzlaştırma benzeri ancak daha geniş kapsamlı bir düzenleme" olarak kabul etmiştir. CGK 2017 tarihli içtihadında ise aynı normu bu defa "davanın ve cezanın düşmesine imkân sağlayan özel bir etkin pişmanlık hükmü” olarak nitelendirmiştir.90

Kanaatimizce İIK'nin 354/1. maddesiyle getirilen sistem; CGK'nin içtihatlarının aksine ne uzlaştırma benzeri bir düzenleme ne de etkin pişmanlık hükmü niteliğindedir. İIK'nin bu norm ile ceza hukukunun suçlulukla mücadele, genel ve özel önleme gayelerinden ${ }^{91}$ nispeten ayrıldığı; bu ilkeleri adeta bir kenara bırakarak asıl amaç olarak alacağın süratle tahsilini gözeten “özel bir dava ve cezanın düşmesi sistemi” kabul ettiği anlaşılmaktadır. Belirtilen özel sistemin kurulmasının cebri icra hukukunun özellikleri ile amacından doğduğunu önemle vurgulamalıyız. Bir diğer ifadeyle, İIKK neredeyse tek şeye odaklanmaktadır: İyi ve süratli işleyen bir cebri icra mekanizmasının kurulması ve işletilmesi, böylelikle alacakların etkin şekilde tahsili. İIK, bu amaca yönelik olarak da kendi özel "dava ve cezanın düşmesi sistemini” ortaya koymuştur.

Hemen belirtmeliyiz ki, İIK'nin 354. maddesindeki dava ve cezanin düşmesi sistemi ile uzlaştırma ve etkin pişmanlık kurumları arasında esasl farklllıklar bulunmaktadır. İIK'nin benimsediği dava ve cezanın düşmesi sistemi, ceza hukukundaki şikâyetten vazgeçme sisteminden de oldukça farklıdır. Cebri icra hukukunun özellikleri ve amacından ortaya çıkan $b u$ sistemin ceza hukukundaki şikâyet kurumu ile etkin pişmanlık ile iliş̧isi de irdelenmelidir.

\footnotetext{
89 CGK 5/7/2005, 2005/10-84-90 (UYAP).

90 CGK 14/3/2017, 2017/19-7, 2017/137 (UYAP).

91 Bkz. CENTEL/ZAFER, s. 5-7.
} 


\subsection{Ceza Hukukunda Şikâyet ve Şikâyetten Vazgeçme ile Karşılaştırılması}

\subsubsection{Muhakeme Şartı Olarak Şikâyet Kurumu}

Ceza muhakemesinde soruşturmanın mecburiliği (kanuniliği) ilkesi uyarınca, herhangi bir şekilde suç işlendiği bilgisinin alınmasıyla birlikte resen soruşturma başlatılır ve yürütülür; soruşturma sonunda suçun işlendiği hususunda yeterli delil elde edilmesi durumunda ise kamu davası açılarak kovuşturma başlatılır. Bazı hallerde, soruşturmanın veya kovuşturmanın başlatılması veya belirli muhakeme işlemlerinin yapılması belli şartların gerçekleşmesine ya da engellerin bulunmamasına bağlı tutulmuş olabilir ki, bunlara ceza muhakemesinin şartları denilmektedir. ${ }^{92} \mathrm{Bu}$ anlamda "şikâyetin gerçekleşmiş olması" ceza muhakemesinin yürüyüşüne etki eden bir muhakeme şartı niteliğindedir. Nitekim, TCK'nin 73/1. maddesinde şikâyet şartı gerçekleşmediği takdirde soruşturma ve kovuşturma yapılamayacağ belirtilmiştir.

Ceza hukukunda bazı fiiller -görece olarak daha az tehlikelilik, haksızlık içerdiği düşüncesiyle- takibi şikâyete bağlı suç olarak kabul edilmiştir. Bir diğer anlatımla, takibi şikâyete bağlı suçlar; kamu adına takibinde fayda, zorunluluk mülahaza edilmeyen fiillerdir. Bu tür fiillerin soruşturma ve kovuşturması şikâyete bağlı kılınmıştır. Soruşturulması ve kovuşturulması şikâyete bağlı olan suç hakkında yetkili kimse altı ay içinde şikâyette bulunmadığı takdirde soruşturma ve kovuşturma yapılamayacaktır (TCK md. 73/1). İIK'de ise, fiilin öğrenildiği tarihten itibaren üç ay ve her halde fiilin işlendiği tarihten itibaren bir yıl geçmekle şikayet hakkının düşeceği kuralına yer verildiğini ifade etmeliyiz (md. 347).

Suçun tâbi olduğu zamanaşımı süresini geçmemek şartıyla şikâyet süresi, şikâyet hakk1 olan kişinin fiili ve failin kim olduğunu bildiği veya öğrendiği günden başlayacaktır (TCK md. 73/2).

92 Kısaca "muhakeme şartları" olarak adlandırılan kavram için bkz. KUNTER/ YENİSEY/ NUHOĞLU, s. 650-652.

ÖZTÜRK/ TEZCAN/ ERDEM/ SIRMA GEZER/ SAYGILAR KIRIT/ALAN AKCAN/ ÖZAYDIN/ ERDEN TÜTÜNCÜ/ ALTINOK VILLEMIN/ TOK, s. 42 vd. ŞAHIN, Cumhur/ GÖKTÜRK, Neslihan: Ceza Muhakemesi Hukuku -I- , Gözden geçirilmiş ve güncellenmiş 10. Bası, Seçkin Yayınevi, Ankara 2019, s. 53-58. (ŞAHIN/ GÖKTÜRK -I). CENTEL/ ZAFER, s. 656. 
İcra ve İflas Kanununun On Altıncı Babındaki Takibi Şikayete Bağlı Suçlarda...

Şikâyetin konusu "olay" olup, şikâyet eden kimse kendisine zarar veren olayı, belli bir kişinin eylemini şikâyet ederek bu olayın muhakeme konusu edilmesini istemekte; bu fiilden dolayı cezalandırılmasını talep etmektedir. ${ }^{93}$ Şikâyetçinin olayı hangi suç olarak nitelendirdiği ise, tabii ki soruşturma makamlarını bağlamayacaktır.

Şikâyet kurumu ile uzlaştırma arasındaki ortak nokta, her ikisinin de muhakeme şartı olmasıdır. ${ }^{94}$ Ancak, uzlaştırma yoluna başvurulması için yeterli suç şüphesinin varlığı yani soruşturma yapılması şart olduğundan takibi şikâyete bağlı suçlarda şikâyet yapılmamış veya geri alınmış ise soruşturma yapılamayacağından uzlaştırma da yapılamayacaktır. Bu itibarla, şikâyetin geri alınmasının uzlaştırmadan daha lehe bir düzenleme olduğu ifade edilmelidir. ${ }^{95}$

\subsection{2. Şikâyetten Vazgeçme ve Feragat}

"Vazgeçme" terimine hakkı hiç kullanmamak anlamının yüklenmesi gerekli iken; TCK, "kullanılan şikâyet hakkının geri alınması" anlamındaki "vazgeçmeyi” düzenlemiştir. ${ }^{96}$ TCK'nin perspektifiyle şikâyetten vazgeçme, şikâyet hakkı kullanıldıktan sonra bu hakkın geri alınmasıdır. ${ }^{97}$

Şikâyetten vazgeçmenin hukuki sonuç doğurması sanığın kabulüne bağlıdır (TCK md. 73/6). Takibi şikâyete bağlı suçlarda kural olarak suçtan zarar gören kişinin vazgeçmesi davayı düşürmekte; ancak hükmün kesinleşmesinden sonraki vazgeçme cezanın infazına engel olmamaktadır (TCK md. 73/4). Şikâyetin bölünmezliği veya sirayeti olarak ifade edilen ilke gereğince; iştirak halinde işlenmiş suçlarda sanıklardan biri hakkındaki şikâyetten vazgeçme, diğerlerini de kapsayacaktır (TCK md. 73/5).

Vazgeçmeyle şikâyet hakkı düşmüş olacağından, aynı olay hakkında bir daha şikâyette bulunulamayacaktır. Şikâyetten vazgeçme şahsi haklardan

93 KUNTER/ YENISEY/ NUHOĞLU, s. 670. CENTEL/ ZAFER, s. 664.

94 Uzlaştırma kurumunun mahkemelerin iş yükünü hafifletmek ve mağduru koruma amacına yönelmiş bir muhakeme şartı olduğuna dair ayrıca bkz. ŞAHİN, GÖKTÜRK -I, s. 49.

95 ÖZBEK, Veli Özer: "Ceza Muhakemesi Hukukunda Uzlaştırma Kurumunun 6763 Sayılı Kanun Hükümleri Çerçevesinde Değerlendirilmesi”, Ceza Hukuku Dergisi, Sa. 32, Aralık 2016, s. 26-27. (ÖZBEK, V. Ö., 2016).

Mağdurun şikâyetten vazgeçme hakkını kullanmasının uzlaştırma prosedürünü engellediğine ilişkin bkz. CENTEL/ZAFER, s. 553

96 CENTEL/ ZAFER, s. 680-681.

97 CENTEL/ ZAFER, s. 681.

642 Ankara Hacı Bayram Veli Üniversitesi Hukuk Fakültesi Dergisi C. XXIV, Y. 2020, Sa. 4 
vazgeçildiği anlamına gelmez; ancak şikâyet hakkı bulunan kimse vazgeçtiği sırada şahsi haklarından da vazgeçtiğini ayrıca açıklamış ise, artık hukuk mahkemesinde de dava açamaz (TCK md. 73/7). Şikâyetten vazgeçme bir muhakeme engeli olup; bu durumda düşme kararı verilecektir (TCK md. 73/4, CMK md. 223/8).

Feragat kelimesi, "ferağ” kökünden gelmekte olup; "vazgeçme, bırakıp terk etme, bir mülkün tasarruf, sahip olma hakkın başkasına terk etme" anlamına gelmektedir. ${ }^{98}$ Şikâyetten feragat ise, bu hakkın kullanılmasından vazgeçme, bu hakkın kullanılmayacağının belirtilmesi anlamındadır. Uygulamada şikâyetten feragate, "şikâyet hakkından vazgeçme" de denilmektedir."9 Feragat ile vazgeçme arasındaki temel fark; feragatin tek taraflı irade beyanı açıklamasıyla hukuki sonuç doğuran bir işlem olmasına karşılık; vazgeçmenin hukuki ilişkinin karşı tarafının kabulüne bağlı olmasıdır. Kuşkusuz, şikâyetten vazgeçme (şikâyetin geri alınması) iki taraflı bir işlemdir. Bunun sebebi, sanığın korunması düşüncesidir. Aksi halde bir şahsın masum birisi hakkında şikâyette bulunup sonra vazgeçmesi ve onu affetmiş gibi bir hal alması, o kimsenin masumiyetini ispata firsat vermeden davanın düşmesine imkân tanınması ve failin cezalandırılmasını ferde bırakmak olurdu ki böyle bir durum şikâyet hakkının amacı ile bağdaşmayacaktır. ${ }^{100}$ IİK'de şikâyetten feragat halinde artık bu feragatten dönülmesi mümkün görülmemektedir. ${ }^{101}$

\subsection{3. İcra ve İflas Hukukunda Şikâyet Usulü ve Şikâyet Kurumundan Farklılıkları}

IIIK “ayrı bir şikâyet ve şikâyet hakkının düşmesi usulü ile dava ve cezanın düşmesi sistemi” oluşturarak (md. 354); TCK'nin şikâyet usulü, süresi ve şikâyetten vazgeçmeye ilişkin temel kurallarından ayrılmıştır. İcra suçlarının özelliklerinden kaynaklanan bu özel sistemin temel farklılıklarını siralayalım:

-Şikâyetin hukuki sonuçları bakımından: Şikâyet, kural olarak ceza muhakemesi hukukunda sadece soruşturma evresini başlatabilmektedir. İIK'ye göre ise şikâyet, kovuşturma evresini başlatma gibi önemli bir hukuki sonuç

\footnotetext{
98 DEVELLİĞLU, Ferit: Osmanlıca-Türkçe Ansiklopedik Lûgat, 25. Baskı, Aydın Kitabevi, Ankara 2008, s. 257.

99 GÜNGÖR, Devrim: 5237 ve 5271 Sayılı Kanunlar Işı̆̆ında Şikâyet Kurumu, Yetkin Yayınevi, Ankara 2009, s. 69- 70.

100 KUNTER/ YENİSEY/ NUHOĞLU, s. 674-675.

101 KÜRTÜL, s. 577.
} 
doğurmaktadır. Zira, İIK'ye göre şikâyet dilekçesini (veya dava beyanını) alan icra mahkemesi duruşma için hemen bir gün belirleyip şikâyetçinin imzasını alarak sanığa celpname gönderecektir. Kısacası, İ̈K sisteminde şikâyet dilekçesi doğrudan kovuşturma evresini başlatma hukuki sonucunu doğurmakta; bu yönüyle "dava açan belge" niteliği taşımaktadır (md. 349/1). Şikâyet dilekçesinin CMK'nin 170. maddesindeki iddianamenin içermesi gereken zorunlu unsurları içermesinin gerekmediği ise, kuşkusuzdur. ${ }^{102}$

TCK'ye göre yapılacak şikâyet başvurusunda, söz edilen hukuki sonuçların hiçbirisi söz konusu olmayıp; burada şikâyetin sadece "soruşturma evresini başlatan" bir hukuki işlem olduğunu hatırlatalım.

-Şikâyet süresi bakımından: TCK' deki fili ve faili öğrenmeden itibaren başlayan altı aylık şikâyet süresi zamanaşımı süresine kadar uzayabilmektedir. Oysa İIK'ye göre filin ögrenilmesinden itibaren üç ay ve her halûkarda filden ${ }^{103}$ itibaren bir yıl geçmekle şikâyet hakkı düşmektedir. Bu süreler hak düşürücü süreler olup mahkemece resen nazara alınacak; süresinden sonra şikâyette bulunulmuşsa İIK'nin 347. maddesi gereğince şikâyet hakkının düşmesine karar verilecektir. ${ }^{104}$ Cebri icranın işleyişinin önündeki maniaları seri şekilde kaldırmaya yönelik amacı karşısında TCK'deki şikâyet süresinin çok uzun kaldığı; bu gayeyle İIK'nin oldukça kısa bir şikâyet süresi benimsediği muhakkaktır.

- Şikâyetin yapılacağı merci bakımından: Ceza muhakemesinde şikâyet kural olarak Cumhuriyet savcılığına veya kolluğa yapılmakta iken (CMK md. 158); İ̈K'ye göre şikâyet doğrudan icra ceza mahkemesine yapılmaktadır. ${ }^{105}$

102 Krş. MUŞUL, 2013, s. 1848.

103 İ̈K'de "suç" yerine "fiill" teriminin kullanılarak KK'ye uyum sağlanmak istendiğine dair ayrıca bkz. ÖZTÜRK/TEZCAN/ ERDEM/ SIRMA GEZER/ SAYGILAR KIRIT/ALAN AKCAN/ ÖZAYDIN/ ERDEN TÜTÜNCÜ/ ALTINOK VILLEMIN/ TOK s. 825.

104 MUŞUL, 1998, s. 145-146.

Şikâyet süresinin başlaması bakımından öğrenme eyleminin ne zaman olduğunun her türlü delille ispat edilebileceğine ve buna dair somut örnekler için ayrıca bkz. YILDIZ, s. 230.

105 “...Ş̧ikâyete tabi olduğu belirtilen bu suçlarla ilgili olarak, şikâyetin doğrudan icra ceza mahkemesine yapılması gerektiğinden, 5271 sayılı Yasanın 170. maddesi uyarınca iddianame düzenlenmesine gerek bulunmadığı gibi, anılan Yasanın 170. ve devamı madde hükümlerinin de bu suçlar yönünden uygulanmasına olanak bulunmamaktadır...." CGK 13/2/2007, 2007/17.HD-16, 2007/28. (UYAP).

Şüpheli bakımından ağır sonuçlar doğuran bu suçlarda da Cumhuriyet savcıllğınca soruşturma yapıldıktan sonra kamu davası açılması gerektiği önerisi için bkz. SARI, s. 197-198. 
-Şikâyetle birlikte delil sunma zorunluluğu bakımından: Ceza muhakemesi hukukunda resen araştırma ilkesi geçerli olduğu için suçun takibi şikâyete bağlı olsa bile sadece fiil hakkında şikâyette bulunmak yeterli olup; suçun delillerini ve failin kimliğini dahi bildirmeye gerek yoktur. Şikâyetin içeriği hakkında herhangi bir sınırlama olmadığ 1 gibi filin cezalandırılmasını isteyen herhangi bir ifadenin varlığı şikâyette bulunmak için yeterlidir. 106 Hâlbuki İIK sisteminde, şikâyetçi dilekçe veya beyanında göstermiş olduğu delillerle bağlıdır (İ̈K md. 351). Bu bağlamda, şikâyet dilekçesinde şüphelilerin isimleri ile fiile ilişkin bilgilerin de yer alması zorunludur. ${ }^{107}$

-Kovuşturmayı takip zorunluluğu bakımından: Ceza muhakemesi hukukunda şikâyetçinin kovuşturmayı takip etme zorunluluğu bulunmamaktadır. Buna karşın, icra ceza muhakemesinde şikâyetçi belirli zamanda duruşmaya gelmez ${ }^{108}$ ve/veya vekil de göndermezse şikâyet hakkının düşmesine karar verilecektir (İ̈K md. 349/2,6).

-Şikâyetten vazgeçmenin zamanı ve etkisi bakımından: TCK'de hükmün kesinleşmesinden sonraki vazgeçme cezanın infazına engel olmamaktadır (md. 73/4). Hâlbuki İiK'de şikâyetten feragat halinde dava ve bütün neticeleriyle beraber ceza düşmekte; yani infaz aşamasında dahi vazgeçme hukuki sonuç doğurmaktadır. Şikâyetten vazgeçme usulü İ̇K'de öngörülmemiş olup, ${ }^{109}$ şikâyetçinin vazgeçme yönündeki irade beyanının açıklıkla ortaya konulması yeterlidir. ${ }^{110}$

\section{UZLAŞTIRMA KURUMU ILE DAVA VE CEZANIN DÜŞMESİ SISTEMI ARASINDAKI FARKLILIKLAR}

İIK'nin 354. maddesindeki dava ve cezanın düşmesi sistemi ile uzlaştırma usulü arasında esaslı farklılıklar bulunmaktadır. Bu bağlamda ilk olarak birbirinden kurumsal çerçeve bakımından tamamen farklı olduğu için

\footnotetext{
${ }^{106}$ CENTEL/ZAFER, s. 102-103.

${ }^{107}$ MUŞUL, 2013., s. 1848.

108 “İIK'nin 349. maddesinin 6. fikrasındaki, "şikâyetçi muayyen zamanda gelmez ve vekil de göndermezse şikâyet hakkı düşer" biçimindeki düzenleme karşısında, müşteki vekilinin 12.05.2006 tarihli oturuma herhangi bir mazeret bildirmeden katılmamasından dolay1 yerel mahkemece müştekinin şikâyet hakkının düşmesine karar verilmesi gerekirken, direnme kararı verilmesinde isabet bulunmamaktadır." CGK. 8/12/2009, 2009/154, 2009/282. (UYAP).

${ }^{109}$ Buna dair eleştiri için ayrıca bkz. ÇOLAK, s. 93.

${ }^{110}$ Şikâyetçinin şikâyetten vazgeçme iradesini hiçbir duraksamaya yol açmayacak bir biçimde açıklaması gerektiğine dair bkz. YILDIZ, s. 232.
} 
söz edilen fiiller yönünden uzlaştırma hükümleri uygulanamayacaktır. İkinci olarak, terminolojik bakımdan konuya bakıldığında İ̈K sisteminin uzlaştırma kurumuna uygun düşmeyeceği ortaya çıkmaktadır. Üçüncü olarak ise, $\mathbf{I I} K$ 'nin getirdiği sistem uygulanma (yürütme) usulü bakımından uzlaştırmadan farkl11ıklar içermektedir. Son olarak ise, usul ekonomisi ilkesine ve icra ceza muhakemesinin amaçlarına uygunluk bakımından farklılıklar bulunmakla; İIK'nin on altıncı babında düzenlenen takibi şikâyete bağlı suçlarda uzlaştırma hükümlerinin uygulanmasına imkân bulunmamaktadır. Söz edilen tüm bu farklılıkların ayrıntılı olarak irdelenmesi yararlı olacaktır.

\subsection{Kurumsal Çerçeve Bakımından Farklılıklar}

\subsubsection{Kurumların Amaçları Bakımından Farklıııklar}

İIK'nin davanın ve cezanın düşmesi sistemi ile uzlaştırma kurumu arasındaki en önemli fark iki kuralın amacından kaynaklanmaktadır. Şöyle ki, "mağdurun zararının giderilmesi (edimin ifası)" uzlaştırma kurumunda fail ile mağduru bir araya getirip onu toplumla bütünleştirerek hapsetmeksizin iyileştirme düşüncesini gerçekleştirme süreci içinde sadece "mağdurun haklarını da gözetmenin aracı" olarak karşımıza çıkmaktadır. Uzlaştırma usulünde mağdurun zararının gönüllü olarak telafi edilmesi, zararların maddi olarak telafi edilmesinden daha kapsamlıdır. Duruma göre; bir özür, açıklama yapılması, mağdurun yaşadıklarının dinlenilmesi gibi şekillerde de -fail tarafindan bizzat yerine getirilebilecek nitelikte olmak şartıyla- edim ortaya çıkabilecektir. ${ }^{111}$ Kısacası, uzlaştırmada edimin ifası (mağdurun suçtan doğan mağduriyetinin -zararının giderilmesi) sadece ve sadece bir araçtan öte bir şey değildir. ${ }^{112}$

İIK'nin on altıncı babındaki takibi şikâyete bağlı fiiller yönünden ise, edimin (borcun) ifası tamamen "amaç" niteliğindedir. Gerçekten, IİK sisteminde bazı fiillerin suç olarak tanımlanması suretiyle korunan hukuki yarar, takip sisteminin iyi işlemesi ve bu çerçevede alacaklının alacağına bir an önce kavuşmasını sağlamaktan öte bir şey değildir. İIK sisteminin odak noktasının "alacakların tahsili" olduğu gözetildiğinde icra suçlarında borcun ifasının amaç olduğu açıkça ortaya çıkmaktadır. Kısacası, edimin ifası uzlaştırmada sadece ve sadece "araç" iken; IIIK sisteminde ise "amaç" tır.

\footnotetext{
${ }^{111}$ Bu konuda ayrıca bkz. ÇETİNTÜRK, s. 558-576. EKİCİ ŞAHIN/ YEMENİCI, s. 497-498.

112 Zira, uzlaştırma usulünde, zararın tazmini bir araç olarak kullanılmakta ve onarıcı adaletin bir parçası olarak tazmin, geçmişe yönelik olmaktan ziyade gelecekte taraflar arasında daha sağlam bir ilişki kurulmasına hizmet etmektedir.

Bkz. ÇETINTÜRK, s. 405.
} 
Uzlaştırma sonucunda uzlaştırmacı, bir rapor hazırlayarak kendisine verilen belge örnekleriyle birlikte uzlaştırma bürosuna sunacaktır. ${ }^{113}$ Uzlaştırma neticesi şüphelinin edimini def'aten yerine getirmesi halinde, hakkında kovuşturmaya yer olmadığı kararı verilir. Edimin yerine getirilmesinin ileri tarihe bırakılması, takside bağlanması veya süreklilik arz etmesi halinde, 171. maddedeki şartlar aranmaksızın, şüpheli hakkında kamu davasının açılmasının ertelenmesi kararı verilir (CMK md. 253/19). Kısacası, uzlaştırma prosedürü sonucunda öncelikle sanığın edimi defaten ödemesi beklenmektedir. Bu gerçekleşmez ise, uzlaşma raporu veya belgesi, İIK'nin 38. maddesinde yazılı ilam mahiyetini haiz belgelerden sayılmaktadır (CMK md. 253/19). Yani uzlaştırma usulü sonucunda elde edilen şey, (eğer rızaî tazmin gerçekleşmemişse) ilam mahiyetinde bir belgeden ibaret kalabilir. ${ }^{114}$ $\mathrm{Bu}$ durumda, hem faile karşı ilamlı icra takibinde bulunulabilecek hem de fail hakkında kamu davası açılacaktır. ${ }^{115}$

İIK perspektifinden konuya bakıldığında Kanun'un on altıncı babındaki suçlarda, kesinleşmiş, yürüyen bir icra takibi zaten mevcuttur. Dolayısıyla bu suçlarda uzlaştırma usulüne başvurmak; "yürüyen cebri icra süreci sırasında işlenen bir fiil sebebiyle -uzlaştırma usulünün başarısız sonuçlanması sebebiyle- ilam mahiyetinde yeni bir belge elde ederek yeni, ikinci bir cebri icra prosedürü başlatmak" gibi anlamsız bir duruma neden olacaktır. Kısacası, anılan suçlarda uzlaştırma prosedürüne başvurmak şu anlama gelmektedir: Yürüyen cebri icra sürecinin önündeki maniaları icra ceza muhakemesi ile kaldırmak isterken uzlaştırma sonucunda yeni bir cebri icra prosedürü başlatmak! Açıkçası, böyle bir girişim; muhakemeyi bir kısır döngüye sevk etmekten başka bir şey olmayıp; icra suçlarında korunan hukuki yararın da bu olmadığ kuşkusuzdur.

Açıklanan sebeplerle, getiriliş amacı ve konusu tamamen farklı olan iki kurumun adeta birbirinin içine geçirilmesi suretiyle İIK'deki takibi şikâyete bağlı suçlara "dava ve cezanın düşmesi”" halleri dışında bir de uzlaştırma kurumunu uygulamaya girişmek; İ̈K'nin sistemine temelden farklı bir mekanizma olan alternatif uyuşmazlık çözüm modeli olan uzlaştırmayı raptetmeye, eklemeye kalkışmak olacaktır. Bu durum ise, IİK ve uzlaştırma sisteminin kurumsal temelleri ile bağdaşmayacaktır.

\footnotetext{
${ }^{113}$ EKİCI ŞAHİN/ YEMENİCi, s. 498-499.

114 Ayrıca bkz. ÇETINTÜRK, s. 580. EKİCI ŞAHİN/ YEMENİCI, s. 503.

${ }^{115}$ ÇETINTÜRK, s. 580.
} 
İcra ve İflas Kanununun On Altıncı Babındaki Takibi Şikayete Bağlı Suçlarda...

\subsubsection{Kurumların Uygulanabileceği Muhakeme Dalları Bakımından Farklılıklar}

Uzlaştırma, CMK'nin 253 vd. maddelerinde düzenlenen ve maddi ceza hukukuna dair etkileri de (davanın düşmesi kararı verilmesi gibi) bulunmakla birlikte ceza muhakemesi hukuku dalına ait olan bir kurumdur. ${ }^{116}$ $\mathrm{Bu}$ bağlamda, icra ceza muhakemesinin kendine özgü niteliğinin hatırdan çıkarılmaması gereklidir. Böylelikle, salt ceza muhakemesi hukuku alanına ait olan uzlaştırma kurumunun inceleme konumuz olan fiiller yönünden uygulanabilip uygulanamayacağı sorununun çözümü için bu özel muhakeme dalının nitelikleri irdelenmelidir.

\subsubsection{1. İcra Ceza Muhakemesinde Soruşturma Evresinin Bulunmaması Sebebiyle Uzlaştırmanın Uygulanamayacağı}

İcra ceza muhakemesinin özgü sistemi içinde ceza muhakemesine ait uzlaştırma kurumunun uygulanması mümkün gözükmemektedir. Kuşkusuz CMK, suç muhakemesi hukukuna dair kuralları düzenleyen temel kanundur. İIK'nin on altıncı babındaki takibi şikâyete bağlı fiiller yönünden ise kanun koyucu açıkça suç muhakemesi hukukuna dair temel kurallardan ayrılarak özel bir sistem benimsemiştir. Bunun pozitif dayanaklarını hatırlayalım: Şikâyet dilekçesi ile dava açılması, şikâyetçinin gelmemesi durumunda davanın düşmesi, iddiayı genişletme yasağı, saniğın bir defadan fazla soruşturmanın genişletilmesini isteyememesi, sanı̆̆ın savunması alınmaksızın da hürriyeti bağlayıcı cezaya hükmolunabilmesi, Cumhuriyet savcısının mahkeme yanında yer almaması gibi.

İIK'nin söz ettiğimiz normları da açıkça göstermektedir ki -takibi şikâyete bağlı suçlar yönünden- icra ceza muhakemesinde Cumhuriyet savcısı tarafından düzenlenecek iddianame ile açılmış bir ceza davası bulunmamakta, dolayısıyla klasik anlamda bir "suç muhakemesi" söz konusu olmayıp; kendine özgü bir ceza davası bulunmaktadır. Bu kendine özgü ceza muhakemesinin "suç soruşturması ve kovuşturması" niteliğinde olmadığı; bu alana ait olmadığ kuşkusuzdur. Gerçekten, icra ceza muhakemesinde soruşturma evresi hiç bulunmayıp; sadece şikâyet dilekçesi ile başlayan bir kovuşturma evresi (icra ceza davası) bulunmaktadır. Bu farklılık dahi, yürütülen muhakemenin "teknik anlamda suç muhakemesi” olmadığını ortaya koymak için tek başına yeterli bir olgudur.

\footnotetext{
116 Uzlaştırma, ceza adalet sisteminin bir parçası olup onunla bütünleşen uygulamalar şeklindedir ve uzlaştırma sonunda varılan anlaşma görülmekte olan dava üzerinde mutlaka bir etkiye sahip olacaktır. Bu konuda ayrıca bkz. ÇETINTÜRK, s. 147.
} 
CMK'nin 253. maddesi, uzlaştırma kurumunun temel (aslî) kuralı niteliğinde olup; soruşturma evresinde Cumhuriyet savcısının gözetiminde uzlaştırmacı tarafından gerçekleştirilecek uzlaştırma usulüne yer vermektedir. Bu normdan da açıkça anlaşılacağ üzere, uzlaştırma -kural olarak-soruşturma evresinde uygulanacak bir usuldür. Uzlaştırmaya tâbi olduğu soruşturma dosyasından açıkça anlaşılan işlerde uzlaştırma usulü uygulanmaksızın düzenlenen iddianamenin Cumhuriyet başsavcılığına iadesine karar verileceğine dair kural da "uzlaştırmanın en geç iddianamenin düzenlendiği tarihe kadar gerçekleştirilmesini" mecbur kılmaktadır. ${ }^{117}$ Gerçekten, uyuşmazlığın dava açılmaksızın, mahkeme önüne götürülmeksizin, mahkeme dışında alternatif çözüm yöntemiyle giderilmesi gayesi nazara alındığında da uzlaştırma usulünün soruşturma evresinden sonra uygulanmasının işin tabiatına ve amacına aykırı olduğu apaçık ortaya çıkmaktadır.

İcra ceza muhakemesinde -takibi şikâyete bağlı suçlar yönündensoruşturma evresi zaten yoktur. Haliyle soruşturma evresi bulunmayıp uyuşmazlık doğrudan şikâyet ile mahkeme önüne götürülünce mahkeme dış1 çözümden; uyuşmazlığı mahkeme önüne götürmeksizin çözümden; alternatif, dostane çözümden kısacası uzlaştırmadan söz etmek de anlamsız olacaktır. Dolayısıyla, İIK'nin on altıncı babındaki takibi şikâyete bağlı fiiller yönünden suç soruşturması ve doğal olarak soruşturma evresi de söz konusu olmayınca CMK'nin 253. maddesindeki Cumhuriyet savcısı gözetimindeki uzlaştırma usulünden de bahsetmek beyhude ve temelsiz bir çaba olarak gözükmektedir.

CMK'nin 253/4. maddesine göre, uzlaştırma usulünün uygulanabilmesi için soruşturma konusu suçun uzlaşmaya tâbi olması yeterli olmayıp; kamu davası açılması için yeterli şüphenin bulunması da gereklidir. ${ }^{118}$ Kısacası, Cumhuriyet savcısının kamu davası açmaya yeterli şüphe sebeplerinin varlığının mevcudiyetini araştırması gereklidir. Cumhuriyet savcısı uzlaştırma yoluna başvurabilmek için soruşturma yapmalı ve kamu davası açılmasına

117 EKİCI ŞAHİN/ YEMENİĊ, s. 478-479.

Uzlaştırma uygulamasının soruşturma aşamasıyla sınırlı tutulması isabetli olmayıp muhakemenin her aşamasında uzlaştırmaya gidilmesinin mümkün olması gerektiğine dair ayrıca bkz. ÇETINTÜRK, s. 457-458.

Uzlaştırmanın asıl olarak duruşmada vicahi olarak gerçekleşmesinin asıl olduğuna ve böylelikle kuruma güven duyulacağına dair bkz. ŞAHİN, s. 232.

${ }^{118}$ CMK md. 253/4: "Soruşturma konusu suçun uzlaşmaya tâbi olması ve kamu davası açılması için yeterli şüphenin bulunması hâlinde, dosya uzlaştırma bürosuna gönderilir.” 
yeterli şüphe bulunup bulunmadığını araştırmalıdır. ${ }^{119}$ İ̈K'nin on altıncı babındaki şikâyete bağlı suçlarda soruşturma evresi olmayınca böyle bir araştırma da mümkün değildir.

Sonuç olarak, uzlaştırmanın -kural olarak uygulanabileceği evresoruşturma evresi olup, Cumhuriyet savcısının soruşturma yaparak kamu davası açmaya yeterli delilin mevcudiyetini araştırması gereklidir. $\mathrm{Bu}$ bağlamda, İIK'nin on altıncı babındaki takibi şikâyete bağlı suçlar yönünden soruşturma evresi zaten söz konusu olmayıp şikâyet dilekçesiyle dava açıldığından bu suçlar yönünden uzlaştırma hükümlerinin uygulanabileceği bir muhakeme evresi bulunmamaktadır. Dolayısıyla anılan fiiller yönünden uzlaştırma uygulamasının ne fiilen ne de hukuken mümkün olamayacağı; bunun kurumsal ve kavramsal olarak imkânsızlığı da apaçık ortaya çıkmaktadır.

\subsubsection{Mahkeme Tarafından Uzlaştırma Hükümlerinin İcra Ceza Muhakemesinde Uygulanamayacağı}

İIK'nin on altıncı babındaki takibi şikâyete bağlı suçlar bakımından soruşturma evresi söz konusu olmadığına göre; bu aşamada CMK'nin 254. maddesindeki "mahkeme tarafından uzlaştırma" hükümlerinin anılan fiillere uygulanabileceği düşüncesi akla gelebilecektir. ${ }^{120}$ CMK'nin 254. maddesi "kamu davası açıldıktan sonra kovuşturma konusu suçun uzlaşmaya tâbi olduğunun anlaşı1ması" haline münhasır olan istisnai nitelikte bir hükümdür. ${ }^{121}$ Uzlaştırmanın asıl olarak soruşturma evresinde uygulanmasıyla amaçlanan şeyin de ceza muhakemesinin uzamasina neden olunmasinin engellenmesi olduğ $u^{122}$ bu vesileyle göz önünde bulundurulmalıdır.

Söz edilen norm ile, bazı kendine özgü durumlarda kovuşturma evresinde de uzlaştırma usulünün uygulanabilmesine imkân tanınmaktadır. Belirtilen durumların neler olduğu Uzlaştırma Yönetmeliği’nin 22. maddesinde sınırlı şekilde sayılmış olup, bunlar;

119 ÖZBEK, V. Ö., 2016, s. 13.

Bir düşünceye göre burada, haksızlığın gerçekleştiği konusunda yeterli şüphe bulunması ve failin bu haksızlığın sorumluluğunu kabul etmesinin aranması daha yerinde olacaktı. Bkz. ÇETINTTÜRK, s. 485.

${ }^{120}$ İIK'nin on altıncı babındaki suçlar bakımından uzlaştırma hükümlerinin uygulanabileceği düşüncesine "hukuki dayanaklarının belirtilmeksizin" yer verilen bir çalışma için ayrıca bkz. bkz. YILDIZ, s. 241.

${ }^{121}$ Aynı yönde bkz. ÇETINTTÜRK, s. 450.

${ }^{122}$ ÇETINTÜRK, s. 457. 
a) Kovuşturma konusu suçun hukukî niteliğinin değişmesi nedeniyle uzlaşma kapsamında olduğunun anlaşılması,

b) Soruşturma evresinde uzlaşma teklifinde bulunulması gerektiğinin ilk olarak kovuşturma evresinde anlaşılması,

c) Cumhuriyet savcısı tarafindan iddianame düzenlenmeksizin, iddianame yerine geçen belge ile doğrudan mahkeme önüne gelen uzlaşmaya tâbi bir suçun varlığg1,

ç) Kovuşturma evresinde kanun değişikliği nedeniyle suçun uzlaşma kapsamına girmesi halleridir.

Bahse konu durumlarda ya suçun hukuki niteliğinin değişmesi veya uzlaştırma teklifinde bulunulması gerektiği ilk defa kovuşturma evresinde anlaşılmıştır (Uzlaştırma Yönetmeliği md. 22/1-a,b). İkinci ihtimal olarak, noterler veya hâkim ve savcılar hakkında görev suçları söz konusu olması örneğinde olduğu üzere, suç oluşturan fiil doğrudan iddianame yerine geçen bir belge ile mahkeme önüne götürülmüştür (Uzlaştırma Yönetmeliği md. 22/1-c). Üçüncü ve son ihtimal olarak ise, kanun değişikliği sebebiyle suçun uzlaştırma kapsamına girmesi hali öngörülmüştür.

İIK'nin on altıncı babındaki takibi şikâyete bağlı suçlar bakımından konuya dönüldüğünde yukarıda bahsettiğimiz durumların hiç birinin mevcut olmadığı; dolayısıyla kovuşturma evresinde uzlaştırma usulünün uygulanmasına imkân tanınan şartların mevcut bulunmadı̆̆ı açıkça ortaya çıkmaktadır. Bu itibarla, İIK' deki konumuzu oluşturan suçlar bakımından bu normun da uygulanma kabiliyeti bulunmadığını gerekçeleriyle birlikte ortaya koyacağı.

\subsection{Kamu Davasının Bulunmaması Sebebiyle Uzlaştırmanın Uygulanamayacağı}

CMK'nin 254. maddesi kovuşturma konusu suçun uzlaşmaya tâbi olduğunun "kamu davası açıldıktan sonra anlaşılması haline münhasır" bir uzlaştırma usulünden söz etmektedir. Bu yönüyle bakıldığında, anılan normun uygulanmasının ilk şartı; bir kamu davasının varlığıdır. Bu bağlamda, icra ceza mahkemesine alacaklının şikâyeti ile açılan dava "kamu davası" niteliğinde olmayı; kendine özgü bir ceza davasıdır.

Asıl ceza yargılamasının yapılabilmesi için, kovuşturma zaruri olup; suç isnadı yargılama makamı önüne getirilmeli; kovuşturma görevi devlet adına 
yapılarak, devlet ithamı, toplumsal itham yapılmalıdır. Açıklanan şekilde devletin yürüttügü kovuşturma "kamu davası" olarak adlandırılmaktadır. ${ }^{123}$ CMK’nin İkinci Kitap, İkinci Kısım, Birinci Bölüm başlığı "kamu davasının açılması" şeklindedir. CMK'ye göre, kamu adına ceza davasını açma görevi kamusal iddia makamını temsil eden Cumhuriyet savcısı tarafından yerine getirilir. ${ }^{124}$ Soruşturma evresi sonunda toplanan deliller, suçun işlendiği hususunda yeterli şüphe oluşturuyorsa; Cumhuriyet savcısı, bir iddianame düzenler (md. 170/1-2). Kamu davasının yürütülmesine ilişkin CMK'nin 175/1. maddesine göre ise, iddianamenin kabulüyle, kamu davası açılmış olur ve kovuşturma evresi başlar. ${ }^{125}$

Ceza davasının kamusallığı ilkesi çerçevesinde ${ }^{126}$ CMK'nin söz edilen normlarından da açıkça anlaşıldığı üzere "kamu davası"; suç soruşturmasına ilişkin olarak Cumhuriyet savcısı tarafından ceza muhakemesi hukuku kurallarına göre açılan; davacısı kamu hukuku olan; iddianamenin kabulü prosedürüne tâbi olan, kısacası her aşaması kamu adına takip edilen bir davadır. Halbuki, İ̇K'nin on altıncı babında düzenlenen suçlara ilişkin davalar, alacaklı tarafından sözlü veya yazılı başvuruyla açılan; iddianamenin (veya şikâyet dilekçesinin) kabulü gibi bir muhakeme işlemine tâbi olmayan; davayı takip etmeme durumunda düşme kararı verilen; resen araştırma ilkesinin geçerli olmadı $\breve{g} 1{ }^{127}$ Cumhuriyet savcısı tarafından kamu adına açılmayıp alacaklı tarafından İIK hükümlerine göre açılmış, kendine özgü bir ceza davası niteliğindedir. ${ }^{128}$ Kısacası, İİK'deki anılan davalar "kamu

${ }^{123}$ KUNTER/ YENISEY/ NUHOĞLU, s. 295.

${ }^{124}$ ŞAHIN/ GÖKTÜRK- II, s. 100.

${ }^{125}$ ŞAHIN/GÖKTÜRK- II, s. 79. ÖZTÜRK/ TEZCAN/ ERDEM/ SIRMA GEZER/ SAYGILAR KIRIT/ALAN AKCAN/ ÖZAYDIN/ ERDEN TÜTÜNCÜ/ ALTINOK VILLEMIN/ TOK, s. 625.

İddianamenin kabulüne ilişkin normla birlikte kamu davası açma tekelinin Cumhuriyet savcılığından alınıp; yargısal bir karara bağlandığına dair ayrıca bkz. CENTEL/ ZAFER, s. 583.

${ }^{126}$ Bkz. CENTEL/ ZAFER, s. 519-520.

127 YILDIZ, s. 229.

128 “...müştekinin C.Savcılığına verdiği şikâyet dilekçesinin İcra Ceza Mahkemesine gönderilmek yerine iddianame düzenlenerek dava açılmış olması müşteki aleyhine sonuç doğurmayacaktır. Ancak, şikâyet dilekçesiyle açılması gereken davanın usulüne uygun olmayacak bir biçimde iddianame ile açılmış olması, davayı kamu davası niteliğine de dönüştürmeyecektir." CGK. 8/12/2009, 2009/16.HD-154, 2009/282. (UYAP).

Şikâyet dilekçesiyle açılması gereken davanın usulüne uygun olmayacak biçimde iddianame ile açılmış olmasının dahi davayı kamu davası niteliğine dönüştürmeyeceğine dair bkz. KÜRTÜL, s. 494. 
davası" niteliğinde değildir. ${ }^{129}$ Dolayısıyla, CMK'nin 254. maddesi anlamında uzlaştırma hükümlerinin uygulanması için ön şart olan "bir kamu davasının varlığı" unsurunu karşılaması da mümkün değildir.

\subsection{Kovuşturma Konusu Suçun Uzlaşmaya Tâbi Olduğunun Kamu Davası Açıldıktan Sonra Anlașılmamış Olması Sebebiyle Uzlaştırmanın Uygulanamayacağı}

Uzlaştırma kurumu bakımından CMK'nin 253. maddesi "aslî-birincil norm"; 254. maddesi ise "tal̂̂-ikincil norm" niteliğindedir. ${ }^{130}$ Bir diğer ifadeyle asıl olan uzlaştırma usulünün -kurumun uyuşmazlığı mahkemeye götürmeksizin çözme amaç ve işlevine uygun şekilde- soruşturma evresinde zaten uygulanmış olmasıdır. ${ }^{131}$ Kovuşturma evresinde uzlaştırma prosedürünün uygulanması ancak CMK'nin 254. maddesi ile Uzlaştırma Yönetmeliği'nin 22. maddesinde belirtilen kendine özgü durumlarla sınırlı olarak öngörülmüştür. Söz edilen hâller (ihtimaller) şunlardır:

1) Suçun hukuki niteliğinin değişmesi sebebiyle uzlaştırma usulünün uygulanması gereği,

2) Uzlaştırma teklifinde bulunulması gerektiğinin ilk defa kovuşturma evresinde anlaşılmış olması,

3) Suç oluşturan fiilin iddianame yerine geçen bir belge ile doğrudan mahkeme önüne götürülmesi,

4) Kanun değiş̧ikliği sebebiyle suçun uzlaştırma kapsamına girmesi.

Birinci ihtimal üzerinden örnekleyecek olursak, ceza muhakemesinde suçun nitelik değiştirerek uzlaştırma usulüne tâbi bir suça dönüşebilmesi mümkündür. ${ }^{132}$ Örneğin, yağma suçundan açılan bir kamu davasında, fiilin açıktan hırsılılı niteliğinde ve uzlaştırma kapsamında olduğu kovuşturma

${ }^{129}$ Şahsi dava niteliğinde olduğuna ilişkin ayrıca bkz. ÖZTÜRK/ TEZCAN/ ERDEM/ SIRMA GEZER/ SAYGILAR KIRIT/ALAN AKCAN/ ÖZAYDIN/ ERDEN TÜTÜNCÜ/ ALTINOK VILLEMIN/ TOK, s. 824, dipnot 51.

${ }^{130}$ Mahkeme tarafından yürütülecek uzlaştırmanın istisnai bir yol olduğuna ilişkin bkz. ÖZTÜRK/ TEZCAN/ ERDEM/ SIRMA GEZER/ SAYGILAR KIRIT/ALAN AKCAN/ ÖZAYDIN/ ERDEN TÜTÜNCÜ/ ALTINOK VILLEMIN/ TOK, s. 65.

131 Uzlaştırmanın taraflar ve toplum bakımından sağlayacağ yararların gözetilerek muhakemenin her aşamasında mümkün olması gerektiğine dair ayrıca bkz. ÇETINTÜRK, s. 457-458.

132 ÖZTÜRK/ TEZCAN/ ERDEM/ SIRMA GEZER/ SAYGILAR KIRIT/ALAN AKCAN/ ÖZAYDIN/ ERDEN TÜTÜNCÜ/ ALTINOK VILLEMIN/ TOK, s. 65. 
evresinde anlaşılabilir. Halbuki İIK'nin on altıncı babındaki şikâyete tâbi suçlarda, bu fiillerin tümünün takibi şikâyete bağlı olması niteliği "bu suçlarda ayrı bir soruşturma evresi zaten bulunmadığından" davanın daha başından bellidir. Dolayısıyla, inceleme konumuzu oluşturan suçlar bakımından belirtilen durumun gerçekleşmesi mümkün değildir.

İkinci ihtimali değerlendirecek olursak, -İ̈K'nin on altıncı babındaki takibi şikâyete bağlı suçlarda ayrı bir soruşturma evresi zaten bulunmadığındanuzlaştırma teklifinde bulunulması gerektiğinin ilk defa kovuşturma evresinde anlaşılmış olması gibi bir durum hiçbir şekilde mümkün değildir. Bir an için İIK' deki anılan suçların uzlaştırmaya tâbi olacağını kabul etsek bile- $b u$ durum, kovuşturma aşamasında henüz, ilk defa anlaşılmış bir şey değildir. Aynı faraziyeden devam edersek; bu hâl, yani şikâyete konu fiilin niteliği daha ilk baştan, şikâyet yapılmadan önce zaten bellidir.

Üçüncü ihtimal olan, suç oluşturan fiilin iddianame yerine geçen bir belge ile doğrudan mahkeme önüne götürülmesi durumu inceleme konumuz suçlar yönünden mümkün değildir. İIK' deki anılan suçlarla korunan hukuki değer ile bu suçların failinin ancak haklarında İIKK hükümlerine göre icra takibi yürütülen ve "borçlu" sıfatını haiz kimseler olabileceği ve bunların gerçek kişi veya ticaret şirketlerinin temsilcilerinden oluşabileceği ${ }^{133}$ nazara alınmalıdır. Dolayısıyla anılan fiillerin, yargılanmaları özel usullere tâbi olan bazı kamu görevlileri tarafindan işlenebilecek olan "görev suçu" olarak nitelendirilen biçimde işlenmesi imkânsızdır.

Dördüncü olarak ise, kanun değişikliği sebebiyle suçun uzlaştırma kapsamına girmesi durumu olağan dışı nitelikte bir ihtimaldir. Böyle bir hâlin ortaya çıkması durumunda, CMK'de veya Uzlaştırma Yönetmeliği'nde düzenleme bulunmasa dahi "kanunların zaman bakımından uygulanması ilkesi" çerçevesinde muhakeme devam ettiği sürece uzlaştırma kurumu uygulanabilecektir.

Uzlaştırma Yönetmeliği’nde yer verilen dört ayrı durumu (ihtimali) ayrıntılı olarak değerlendirerek İİK'nin on altıncı babında düzenlenen takibi şikâyete bağlı fiiller bakımından CMK'nin 254. maddesinin

133 Hükmi şahısların muamelelerinde kimlerin ceza göreceği :

İIK Madde 345: "Bu kanunda yazılı suçlar, hükmi bir şahsın idare veya muamelelerini ifa sırasında işlenmiş ise ceza o hükmi şahsın müdürlerinden, mümessil ve vekillerinden, tasfiye memurlarından, idare meclisi reis ve azasından veya murakıp ve müfettişlerinden fiili yapmış olan hakkında hükmolunur." 
uygulanamayacağını gerekçeleriyle birlikte ortaya koymuş bulunuyoruz. Anılan suçlarda soruşturma evresinin bulunmadığını bilen kanun koyucu -şayet isteseydi- bu suçlarda şikâyet başvurusundan önce uzlaştırma yoluna başvurma zorunluluğunu getirebilecek iken bunu da getirmemiş; şikâyette bulunulmasıyla doğrudan ceza davası açılmasını mümkün kılmak suretiyle özel bir muhakeme usulüne bizatihi imkân tanımıştır.

İIK'deki söz edilen suçlarda kapsamlı nitelikte değişiklik 1 Haziran 2005 tarihinde yürürlüğe giren 5358 sayılı Kanun ile gerçekleştirilmiştir. Aynı tarihte uzlaş(tır)ma kurumu da Ceza Adalet Sistemimizde ilk defa kabul edilmiştir. Dolayısıyla, İIK' deki söz edilen suçların tamamını Ceza Adalet Sistemine uygun olarak yeniden düzenleyen kanun koyucunun ${ }^{134}$ bu suçlar yönünden ne o tarihte ne de sonrasında uzlaştırma kurumunun uygulanabilirliğine dair düzenleme yapmamış olması şüphesiz, bilinçli bir tercihtir. Bu itibarla, talî norm niteliğindeki CMK'nin 254. maddesindeki uzlaştırma usulünü İIK'deki anılan fiillere uygulamak anılan normun talî/ikincil niteliğiyle bağdaşmamaktadır.

\subsection{Kavramsal Çerçeve Bakımından Farklılıklar}

Terimler, bir bilim dalının ya da ihtisas alanının kendine has kavramlarını en kısa, en somut ve anlaşılır biçimde ifade eden, alanın uzmanlarının aynı şeyi anlamasına imkân tanıyan özel kelimelerdir. Bu bağlamda hukuk dilini, dilin diğer versiyonlarından ayıran en belirgin özellik, çok sağlam ve oturmuş bir terminolojisinin olmasıdır. ${ }^{135}$ Gerçekten, hukuk biliminde normların tercih ettiği terminolojinin tesadüfi olmayıp; kuralın dayandığı hukuki kurumlarla ilişkisini ifade ettiği kuşkusuzdur. Bu bağlamda, CMK'nin 254. maddesinin tercih ettiği terminolojiden hareket ettiğimizde da anılan fiiller yönünden uzlaştırmanın uygulanamayacağı sonucuna ulaşmaktayız. Konumuza dair öne çıkan terminolojik farklılıkları şöylece sıralayabiliriz:

134 Söz edilen amaç 5358 sayılı Kanun'un Genel Gerekçe'sinde şu sözlerle açıklanmıştır:

“...31.3.2005 tarihli ve 5328 sayılı Kanunla yeni Türk Ceza Kanunu ve buna bağlı olarak bazı kanunların 1 Nisan 2005 olan yürürlük tarihleri 1 Haziran 2005 olarak yeniden belirlenmiştir. Bu çerçevede 2004 sayılı İcra ve İflas Kanununun ceza içeren hükümlerinin yeni Türk Ceza Kanunu çerçevesinde yeniden değerlendirilmesi gerekmektedir.

2004 sayılı İcra ve İflas Kanununda yukarıda açıklanan nedenlerle gerekli değişiklikleri yapmak amacıyla bu Kanun Teklifi hazırlanmıştır...."

Bkz. https://www.tbmm.gov.tr/sirasayi/donem22/yil01/ss915m.htm (Erişim tarihi: 28/1/2020).

${ }^{135}$ AYDEMIR, İbrahim Ahmet: “Türk Hukuk Dili Üzerine Araştırmalar I”, Belleten, 2010, Sa. 2, s. 25. 
İcra ve İflas Kanununun On Altıncı Babındaki Takibi Şikayete Bağlı Suçlarda...

1) CMK'nin 254. maddesi “...kovuş̧urma konusu suç...” tan söz etmektedir. Halbuki CMK'nin 2/1-f maddesine göre; "Kovuşturma, iddianamenin kabulüyle başlayıp hükmün kesinleşmesine kadar geçen evreyi ifade eder." Bu bakımdan icra ceza muhakemesi CMK anlamında bir "kovuşturma evresi" içermemektedir. Çünkü takibi şikâyete bağl1 suçlar yönünden icra ceza muhakemesinde ne iddianame ne de bunun kabulü șeklinde muhakeme ișlemleri yer almamaktadır. Dolayısıyla icra ceza mahkemesinde ortada yürütülen bir kovuşturma bulunmayınca; kovuşturma evresinde mahkeme tarafından yürütülecek bir uzlaştırma işleminden de söz edilemeyecektir.

2) CMK'ye göre gerçekleştirilecek uzlaştırma prosedürü, "soruşturma evresinde", "Cumhuriyetsavcısınıngözetiminde" "uzlaştırmabürosu"nezdinde görevlendirilecek olan "uzlaştırmacı tarafından" gerçekleştirecektir. ${ }^{136}$ Halbuki İIK'nin on altıncı babındaki takibi şikâyete bağlı suçlarda ne soruşturma evresi ne de Cumhuriyet savcısı (kararın görüldü işlemine tâbi tutulması dışında) bulunmamaktadır. Dolayısıyla bu suçlarda uzlaştırma bürosundan ve uzlaştırıcıdan da söz edilemeyecektir.

3) Uzlaştırmanın başarılı olması halinde kovuşturmaya yer olmadığ kararı (KYOK); edimin ifasının ertelenmesi halinde kamu davasının açılmasının ertelenmesi kararı verilecektir. Bunun şartlarının yerine getirilmemesi durumunda ise kamu davası açılacaktır (CMK md. 253/19). Halbuki, takibi şikâyete bağlı suçlar yönünden icra ceza muhakemesinde şikâyet dilekçesi veya beyanının icra ceza mahkemesine verilmesiyle doğrudan açılan bir ceza davası söz konusudur. Dolayısıyla, şikâyet dilekçesi ile doğrudan dava açılan icra ceza muhakemesinde KYOK veya kamu davasının açılmasının ertelenmesi kararı ya da iddianame ile dava açılması söz konusu olamayacağından bu suçlarda uzlaştırma usulünün uygulanamayacağ1 -kavramsal olarak da- bir kez daha ortaya konulmuş bulunmaktadır.

\subsection{Yürütme Usulü Bakımından Farklılıklar}

Söz ettiğimiz kurumsal, düşünsel, amaçsal ve terminolojik farklılıklar sebebiyle İIK'nin on altıncı babındaki takibi şikâyete bağlı suçlar yönünden uzlaştırma hükümlerinin uygulanması mümkün gözükmemektedir. Tüm bu sebeplere ilave olarak IIIK'nin getirdiği düşme sisteminin uzlaştırma

136 Bu konuda ayrıca bkz. EKİCİ ŞAHİN/ YEMENİĊ, s. 480-484. 
kurumundan daha kapsaml olduğu ifade edilmektedir. ${ }^{137}$ Gerçekten, IIIK sistemi, edimin ifasına yönelik olarak uzlaştırma kurumunun getirdiği imkânlardan daha fazlasını -hem de hiçbir usule tâbi olmaksızın- zaten içinde barındırmaktadır.

İIK sistemi ile uzlaştırma kurumunun yürütülme usulüne ilişkin farklılıklar şöyle sıralanabilir:

1) Uzlaştırma için öncelikle failin mağdura karşı bir haksızlık gerçekleştirdiğini ve sorumluluğu üstlenmek istediğini ${ }^{138}$ yani uzlaşmak istediğini kabul etmesi gerekmektedir. Uzlaştırmada failin bu sorumluluğu kabul etmesi, failin uzlaşma sürecine katılmak ve o haksızlığı gerçekleştirdiğini, gerekirse zararı gidermek istediğini kabul anlamına gelmekte; ancak "suçun ikrarı" mânâsı taşımamaktadır. ${ }^{139}$ Halbuki, İ̇K hükümlerine göre dava ve cezanın düşmesi için böyle bir kabul gerekli değildir.

2) Uzlaştırma için fail ve mağdurun anlaşmaları ve bu uzlaşmanın hukuka uygun bir edim karşıllğında olduğunun Cumhuriyet savcısı; kovuşturma evresinde ise hâkim tarafindan belirlenerek evrakın soruşturma dosyasına eklenmesi zorunludur. ${ }^{140}$ İ̇K'deki dava ve cezanın düşmesi usulünde ise, böyle bir muhakeme prosedürüne gerek bulunmamaktadır.

3) Uzlaştırmada fail ile mağdurun herhangi bir şekilde (bir edim karşılı̆̆ında veya edimsiz olarak) "uzlaşmayı kabul etmeleri” şart olduğu halde; İIK'deki dava ve cezanın düşmesi usulü için mağdur (alacaklı) ile hiç

137 UYSAL, s. 1046. Ayn1 yönde bkz. KÜRTÜL, s. 577.

${ }^{138}$ ÇETINTÜRK, s. 482. Krş. CENTEL/ZAFER, s. 555, dipnot 145.

${ }^{139}$ CMK'nin 253. maddesinde daha önce yer verilen "failin suçtan doğan sorumluluğunu kabul etmesi şartı" suçsuzluk karinesine aykırılık oluşturduğu gerekçesiyle eleştirilmiş ve 5560 sayılı Kanunla yapılan değișiklikle kaldırılmıștır. Öte yandan, uzlaştırmada failin bu kabulünün "suçun ikrarı" niteliğinde olmadığı ve onarıcı adalet anlayıșı çerçevesinde uygulanan fail mağdur uzlaştırmasının toplumsal barışa hizmet eden yönüne hizmet etmesi itibariyle değişikliğin isabetli olmadığı da ifade edilmektedir. 5560 sayılı Kanun için bkz. RG. 19/12/2006, 26381.

Bu değişikliğe ilişkin değerlendirmeler için ayrıca bkz. ÇETINTÜRK, s. 484-486. ÖZBEK, M. S., s. 159-160.

AYM'ye göre; “... Failin fiilden dolayı hiçbir sorumluluk duymaması halinde uzlaştırmanın toplumsal barışa hizmet eden ve faili uslandırıcı işlevi yerine getirilmemiş olacaktır. İtiraz konusu kural uygulanırken uzlaşmada şüpheli veya sanığın suçu kabulü, ikrar olarak değil suçtan doğan sorumluluğun kabulü olarak anlaşllmalıdır...." AYM 1/10/2009, 2006/106, 2009/124 sayıl1 kararı için bkz. RG. 8/3/2011, 27868.

${ }^{140}$ CENTEL/ZAFER, s. 559. 
İcra ve İflas Kanununun On Altıncı Babındaki Takibi Şikayete Bağlı Suçlarda...

anlaşmadan, icra dairesine yapılacak bağımsız bir ödemeyle borç itfa edilerek amaca ulaş1labilecektir.

4) Uzlaştırmada, măgdur failden bağımsız olarak tek başına uzlaşma sağlayamamasına rağmen; İ̈K sisteminde mağdurun (alacaklının) failden bağımsız olarak şikâyet hakkından feragat edebilmesi önemli bir fark olarak ortaya çıkmaktadır.

5) Bir diğer temel farkl111k ise, uzlaştırmanın ancak hüküm kesinleşinceye kadar yapılabilmesine karşı1ık, ${ }^{141}$ İIK' ye göre fail ve mağdur (alacaklı) hüküm kesinleştikten sonra dahi anlaşarak veya alacaklı şikâyetten vazgeçerek dava ve cezanın düşmesini sağlamak imkânına sahiptirler.

6) Uzlaştırmada edimin yerine getirilmesinin ileri tarihe bırakılması, takside bağlanması veya süreklilik arz etmesi halinde, şüpheli hakkında kamu davasının açılmasının ertelenmesi kararı verilebilmesi mümkündür (CMK md. 253/19). Gerçekten, bir an için bu suçlarda uzlaştırma usulüne başvurulabileceğini düşündüğümüzde; maddi konusunu bir alacağın oluşturduğu icra suçlarında edimin ifasının ileri tarihe bırakılması veya takside bağlanması gibi yollara başvurulması kuvvetle muhtemeldir. $\mathrm{Bu}$ durumda anılan norma göre kamu davasının açılmasının ertelenmesi kararı verilmesi gerekecektir. Ancak İIK'deki anılan suçlarda şikâyet dilekçesi ile zaten doğrudan dava açıldiğı için muhakeme evrelerinde geriye dönülmezlik ilkesi gereği kamu davasının açılmasının ertelenmesi kararı verilemeyecektir. Bu itibarla, anılan uzlaştırma usulü yönünden İİK'nin on altıncı babındaki takibi şikâyete bağlı suçlara anılan kurumun uygulanmasının teknik olarak da imkânsızlığı ortaya çıkmaktadır.

7) Uzlaştırmada edimin yerine getirilmesinin ileri bir tarihe ertelenmesi, takside bağlanması, süreklilik arz etmesi durumlarında CMK'nin 231. maddesindeki şartlar aranmaksızın, hükmün açıklanmasının ertelenmesi kararı verilecek olup bu durumda ancak ödeme tamamlandıktan sonra düşme kararı verilmesi mümkündür. ${ }^{142}$ Halbuki İIK sisteminde borcun itfas1 konusunda alacakl ile sanık (borçlu) bir vade veya taksit ya da süreklilik konusunda anlaşmaları halinde bu durum şikâyetten vazgeçmeye ve dolayısıyla davanın veya cezanın düşmesine engel bir durum oluşturmamaktadır.

${ }^{141}$ Muhakemenin her aşamasında uzlaştırmaya gidilmesinin mümkün olması gerektiğine dair ayrıca bkz. ÇETINTÜRK, s. 457-458.

142 Ayrıca bkz. BAŞTÜRK, İhsan: Hükmün Açıklanmasının Ertelenmesi, Adalet Yayınevi, Ankara 2014, s. 456-457. ÇETINTTÜRK, s. 581-582. 
Yürütme usulü bakımından ortaya çıkan farkl11ıklardan da görüldüğü üzere, İIK' nin 354. maddesindeki dava ve cezanın düşmesine ilişkin norm, uygulanma usulü bakımından uzlaştırma usulünden daha kapsayıcı imkânlar içermektedir. Bu yönleriyle İIK'nin anılan sisteminin uyuşmazlığın taraflarına (icra ceza muhakemesinde şikâyetçi/alacaklı ile sanık/borçluya) uzlaştırma kurumundan daha kapsaml, basit, esnek ve amaca elverişli uygulama şartları bahşettiği açıkça ortaya çıkmaktadır.

\subsection{Usul Ekonomisi İlkesine ve İcra Ceza Muhakemesinin Amaçlarına Uygunluk Bakımından Farklılıklar}

İcra ceza muhakemesi, takip sisteminin iyi işlemesini sağlama ile alacakların süratle ve kolaylıkla cebri icrası amacına yönelmiştir. Bu bağlamda, uzlaştırma usulünü icra ceza muhakemesinin içine adapte etmek şeklindeki uygulamanın, Anayasamızın 141/son maddesinde "davaların mümkün olan süratle ve en az giderle sonuçlandırılması" şeklinde ifade edilen usul ekonomisi ilkesine de uygun olması gerektiği kuşkusuzdur.

İcra ceza muhakemesinde uzlaştırma usulünün uygulanabileceğini bir an için mümkün gördügüumüzde, uzlaştırmada tarafların bir edim üzerinde uzlaşmaları ancak edimin yerine getirilmesinin ileri bir tarihe ertelenmesi, takside bağlanması, süreklilik arz etmesi durumlarında hem usul ekonomisi ilkesine hem de icra ceza muhakemesinin amaçlarına aykırı sonuçlar da ortaya çıkmaktadır.

Uzlaştırmada, zararın giderilmesi derhal gerçekleşmemiş ise, alacağın tahsili yine mümkün olmayacak; alacaklıya sadece ilam mahiyetini haiz bir "uzlaşma raporu veya belgesi" verilecektir (CMK md. 253/19). Bu belgelerin icra takibine konu edilmesi de gerekebilecektir. Halbuki icra ceza muhakemesine konu teşkil eden uyuşmazlık; bir alacağın tahsiline ilişkin olup; bu ise tek kelimeyle bir özel hukuk uyuşmazlı̆̆ldır. Bu uyuşmazlı̆̆1 çözmek isterken başvurduğumuz uzlaştırma prosedüründe edimin derhal yerine getirilmemesi durumunda şikâyetçiye (alacaklıya) verilecek uzlaştırma raporu veya belgesinin ifasından da yeni bir özel hukuk uyuşmazlı̆̆ doğması muhtemeldir. $\mathrm{Bu}$ yeni, ikinci uyuşmazlığın konusu, uzlaşma sonucundaki edimin ifasıdır. Bu uyuşmazlı̆̆ın doğuş sebebinin ise, uzlaştırma prosedürü olduğu kuşkudan uzaktır.

Kısacası, temelinde özel hukuka ait olan bir alacağın tahsilini icra ceza muhakemesi ile etkin ve süratli biçimde gerçekleştirmek isterken uzlaştırma prosedürüne başvurmak; açıklandığı üzere uyuşmazlığın yeniden bir özel 
hukuk uyuşmazlığına evrilmesine yol açabilecektir. Deyim yerindeyse, söz edilen hâlde "uyuşmazlık içinden uyuşmazlık çıkartmak" veya "cebri icraya yeni bir cebri icra eklemek" olarak ifade edilebilecek tuhaf ve bir o kadar da mantıklı olmayan bir tablo ortaya çıkmaktadır. Bu durum ise, bir kısır döngüden, açmazdan başka bir şey olmayacak; usul ekonomisi ile icra ceza muhakemesinin serilik ve basitlik ilkeleriyle bağdaşmayacağı ve amaca da uygun düşmeyecektir.

\section{SONUÇ}

İcra ceza muhakemesi, odağında alacaklı ve icra takibinin konusu olan alacağın tahsilinin bulunduğu; takip sisteminin iyi işlemesini gerçekleştirme amacına hasrolunmuş bir alana dair pratik ilkeler içeren özel, seri ve kendine özgü bir muhakeme dalıdır. Bu alanın ihtiyaçları temel olarak IİK ile düzenlenmiş; ceza ile hukuk muhakemesi dallarından bazı ilkeler adeta ödünç alınmıştır. Ceza muhakemesinde "maddi gerçeği bulmak" olan temel amacın; icra ceza muhakemesinde "takip sisteminin etkin şekilde işletilmesi" olduğu nazara alındığında amaç bakımından farklılık açıkça ortaya çıkmaktadır. $\mathrm{Bu}$ sebeple, ceza muhakemesinin kurum ve kuralları ancak bünyeye uygun düştüğü ölçüde icra ceza muhakemesine aktarılabilecek ve uygulanabilecektir. İIK'nin on altıncı babındaki takibi şikâyete bağlı suçlar bakımından uzlaştırma usulünün niçin uygulanamayacağını ve bu usule başvurulmasının doğurabileceği sakıncaları şöylece sıralayabiliriz.

1. Öncelikle belirtmeliyiz ki, alternatif uyuşmazlık çözüm mekanizması olan uzlaştırmada, uyuşmazlığı mahkeme önüne götürmeksizin soruşturma evresinde çözümlemek amaçlandiğından İ̈K'deki söz konusu suçlara uzlaştırma usulünün uygulanamayacağı daha baştan ortaya çıkmaktadır. Çünkü anılan suçlarda şikâyet dilekçesiyle uyuşmazlık doğrudan icra ceza mahkemesi önüne gitmiş olduğundan; uzlaştırmaya başvurarak alternatif çözüme ulaşmak gibi bir amaçtan da söz edilemeyecektir. Bu itibarla, İ̇K' deki söz konusu suçlar bakımından uzlaştırma hükümlerinin uygulanabileceği bir muhakeme evresi yani soruşturma evresi bulunmadığından uzlaştırma usulü de uygulanamayacaktır.

CMK'nin 254. maddesindeki "mahkeme tarafından uzlaştırma" hükümlerinin anılan fiillere uygulanabileceği düşüncesi akla gelebilecektir. Unutulmamalıdır ki, CMK'nin 254. maddesi "kamu davası açıldıktan sonra kovuşturma konusu suçun uzlaşmaya tâbi olduğunun anlaşılması" haline münhasır, istisnâ̂ nitelikte bir norm olup, İIKK'deki anılan suçlar yönünden 
bu istisnaî haller de mevcut değildir. Dolayısıyla İİK'deki söz edilen fiiller yönünden uzlaştırma kurumundan beklenen gayenin gerçekleşmesinin imkansızlığı daha davanın başından belli olduğu gibi; bu suçlarda uzlaştırma uygulamasinın muhakemenin evreleri itibariyle ne fiilen ne de hukuken mümkün olamayacağı açıkça ortaya çıkmaktadır.

2. İcra ceza muhakemesinde uzlaştırma kurumunu uygulayabilmek için normatif dayanaklar ve bunun dışa vurumu olan muhakeme işlemlerinin gerekliliği, konunun bir diğer boyutunu oluşturmaktadır. Bu bağlamda, uzlaştırma için öncelikle, yürütülmekte olan bir suç muhakemesi ile soruşturma evresi veya açılmış bir kamu davasının varlığı zorunludur. Oysa ki icra ceza muhakemesinde söz konusu fiillerde, ne soruşturma evresi veya soruşturma konusu suç ne de bir kamu davası bulunmamaktadır. Bu itibarla, uzlaştırma kurumunun uygulanması için gerekli olan tüm bu unsurlar, kısacası uzlaştırmanın hukuki zemini icra ceza muhakemesinde mevcut değildir. İcra ceza muhakemesinde anılan suçlarda uzlaştırma usulünün uygulanması için zorunlu hukuki düzlem var olmayınca burada uzlaştırmanın uygulanmasından söz etmek de hukuken mümkün gözükmemektedir. Kısacası, uzlaştırma kurumunun getirdiği imkânlar ancak suç muhakemesine ve kamu davasina münhasirdır.

3. İcra ceza muhakemesinin odak noktasını "alacağın tahsili" oluştururken; uzlaştırmada "edimin ifası" muhakemenin ve kurumun merkezinde yer almamakta, edimsiz dahi uzlaşılabilmektedir. Çünkü, uzlaştırmanın amacı, uyuşmazlığı mahkeme önüne götürmeksizin dostane yollarla çözmektir. Kısacası, icra ceza muhakemesinde "amaç" olan "alacağın tahsili"; uzlaştırmada "edimin ifası" şeklinde ve "sadece bir araçtan ibaret" kalmaktadır. Dolayısıyla, uzlaştırma kurumu ile icra ceza muhakemesindeki farklılı̆̆ın daha temelden kaynaklandığı görülmektedir.

4. İşleyiş ve kapsam perspektifinden bakıldığında, İIK'nin kendine özgü sistemiyle 354. maddesinde düşme sebepleri anlamında uzlaştırmadan daha kapsamll, basit, esnek ve amaca elverişli uygulama şartlarını bünyesinde barındırdı ̆̆ tartışmasızdır. Hâl böyle iken, mevcut kendine özgü sistemi görmezden gelerek uzlaştırma usulüne başvurmak, muhakemede mesnedsiz ve anlamsız bir çaba olarak gözükmektedir.

5. İIK' deki söz edilen suçlarda uzlaştırma usulüne başvurmak usul ekonomisi ilkesi ile icra ceza muhakemesinin amaçlarına da aykırıdır. Gerçekten, temelinde özel hukuka ait olan bir alacağın tahsilini icra ceza 
muhakemesi ile etkin ve süratli biçimde gerçekleştirmek isterken uzlaştırma prosedürüne başvurmak; -uzlaşılan edimin derhal ve rızaen ifa edilmemesi durumunda- uyuşmazlığın yeni bir özel hukuk uyuşmazlığına dönüşmesine sebep olacaktır. Kısacası, bir uyuşmazlığı çözmeye çalışırken yeni bir uyuşmazlığın çıkmasına yol açmak; muhakemeyi bir çıkmaza, kısır döngüye sevk etmekten başka bir şey değildir. Bu ise, ne usul ekonomisi ilkesiyle ne de icra ceza muhakemesinin gayesiyle bağdaşmayacaktır.

Kısacası, IIIK'nin dava ve cezanın düşmesi sisteminin varliğ ve icra ceza muhakemesinin kendine özgü niteliği karşısında, Kanun'un on altınc1 babında düzenlenen takibi şikâyete bağlı fiiller yönünden uzlaştırma usulünün uygulanamayacağ1 anılan sistem ve usullerin hem kurumsal, amaçsal ve normatif temelleri itibariyle hem de yürütülme biçimi ile usul ekonomisine aykırı sonuçları bakımından ayrıntılarıyla ortaya konulmuş bulunmaktadır. İIK'nin 354/1. maddesindeki kendine özgü, amaca elverişli ve işlevsel "dava ve cezanın düşmesi sistemi" CGK'nin içtihatlarının aksine ne uzlaştırma benzeri bir düzenleme ne de etkin pişmanlık hükmü niteliğindedir. Bu itibarla, 6763 sayılı Kanun değişikliği ile getirilen düzenlemenin İİK'nin on altınc1 babındaki takibi şikâyete bağlı suçları uzlaştırma kapsamına aldığı şeklinde bir yanılgıya düşülmemelidir.

İcra ceza muhakemesinin niteliği, amaçları ve özelliklerini esas almak suretiyle, kurumsal temellerden vazgeçilmeksizin içtihat aykırıllı̆̆ giderilerek problemin çözümlenmesi hayati önemi haizdir. Cebri icra hukukunun etkinliğinin sağlanması yoluyla iyi işleyen bir takip sistemi ile piyasa mekanizmasına, dolayısıyla güçlü bir millî ekonomiye sahip olunması hedefine katkı sağlanması amacına da böylelikle ulaşılabileceğimize inanıyoruz. 


\section{KAYNAKÇA}

Adli İstatistikler 2018, T.C. Adalet Bakanlığı yayını, Ankara 2019. http:// www.adlisicil.adalet.gov.tr/istatistik_2018/istatistik2018.pdf (Erişim tarihi: 6/7/2019).

AKBULUT, Berrin: Ceza Hukuku Genel Hükümler, Adalet Yayınevi, Ankara 2015.

ASHWORTH, Andrew: The Criminal Process An Evaluative Study, Second Edition, Oxford University Press, New York 1998.

AYDEMIR, İbrahim Ahmet: "Türk Hukuk Dili Üzerine Araştırmalar I," Belleten, 2010, Sa. 2, s. 19- 36.

BAŞTÜRK, İhsan: Hükmün Açıklanmasının Ertelenmesi, Adalet Yayınevi, Ankara 2014.

BERZINS, Andrejs/ LINDSAY, Mac: "Mağdur Fail Uzlaşması (VictimOffender Mediation-V.O.M) Seminerinde Sunulan Tebliğ”, Ankara, 12 Haziran 2008.

http://www.undp.org.tr/demGovDocs/MediationCriminalJustice/mac lindsay.doc (Erişim tarihi: 8/5/2019).

CENTEL, Nur/ ZAFER, Hamide: Ceza Muhakemesi Hukuku, Yenilenmiş ve gözden geçirilmiş 15. Bası, Beta Basım, Yayım, Dağıtım A.Ş., İstanbul 2018.

ÇETINTÜRK, Ekrem: Onarıcı Adalet ve Ceza Adalet Sisteminde Uzlaştırma, Adalet Yayınevi, Ankara 2017.

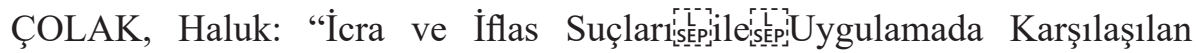
Sorunlar", Bankacılar Dergisi, Sa. 53, İstanbul 2005, s. 72-106.

DEVELLİĞLU, Ferit: Osmanlıca-Türkçe Ansiklopedik Lûgat, 25. Bask1, Aydın Kitabevi, Ankara 2008.

EKİCI ŞAHIN, Meral/ YEMENICİ, Kürşat: “6763 Sayılı Kanunla Yapılan Değişiklikler Işı̆̆ında Ceza Muhakemesi Hukukunda Uzlaştırma", Erzincan Üniversitesi Hukuk Fakültesi Dergisi, C. XIII, Sa. 1, 2018, s. 445-507.

ERCAN, İbrahim: "İcra ve İflas Suçları Üzerine Bazı Düşünceler", Selçuk Üniversitesi Hukuk Fakültesi Dergisi, 2005, C. 13, Sa. 1, s. 7-32. 
İcra ve İflas Kanununun On Altıncı Babındaki Takibi Şikayete Bağlı Suçlarda...

ERIŞ, Uğur: "Ceza Muhakemesi Hukukunda Uzlaştırma ve Uzlaştırma Eğitimi”, Türkiye Barolar Birliği Dergisi, Sa. 137, 2018, s. 241-271.

ERMENEK, İbrahim: “İcra ve İflâs Kanunu'nda Öngörülen Cezaî Hükümler Bakımından Ne Bis İn İdem İlkesinin Uygulama Alanı" Türkiye

Adalet Akademisi Dergisi, Sa.19, Ekim 2014, s. 279-320.

FEYZİĞLLU, Metin: "Uzlaştırma Teklifi ve Taraflara Bildirilmesi”, Uğur Alacakaptan'a Armağan Cilt I, İstanbul Bilgi Üniversitesi Yayınları, İstanbul Haziran 2008, s. 331-337.

GÜNGÖR, Devrim: 5237 ve 5271 Sayılı Kanunlar Işı̆ı̆ında Şikâyet Kurumu, Yetkin Yayınevi, Ankara 2009.

HAFIZOĞULLARI, Zeki: Ceza Normu Normatif Bir Yapı Olarak Ceza Hukuku Düzeni, US-A Yayınc1lık, Ankara 1996.

KAYMAZ, Seydi/ GÖKCAN, Hasan Tahsin: Uzlaşma ve Önödeme, Seçkin Yayınevi, İkinci bask1, Ankara 2007.

KUNTER, Nurullah/ YENISEY, Feridun/ NUHOĞLU, Ayşe: Bir Muhakeme Dalı Olarak Ceza Muhakemesi Hukuku, Beta Basım, Yayım, Dağıtım A.Ş., Onsekizinci bask1, İstanbul 2010.

KURU, Baki: İcra ve İflas Hukuku Eı Kitabı, Tamamen yeniden yazılmış ve genişletilmiş ikinci baskı, Adalet Yayınevi, Ankara 2013.

KÜRTÜL, Mehmet: Açıklamalı - Örnekli - İçtihatlı İcra ve İflas Suçları, Gökçe Ofset Matbaacılık, Ankara 2012.

MUŞUL, Timuçin: İcra ve İflas Hukuku Cilt: II, Gözden geçirilmiş ve genişletilmiş 6. Bask1, Adalet Yayınevi, Ankara 2013. (MUŞUL, 2013).

MUŞUL, Timuçin: İflas Suçları Taksiratı ve Hileli İflas Suçları ile Diğer İflas Suçları, Filiz Kitabevi, İstanbul 1998, s. 7. (MUŞUL, 1998).

NUHOĞLU, Ayşe: "Ceza Hukukunda Zararın Telafi Edilmesi” Prof. Dr. Kenan Tunçomağ’a Armağan, İÜHF Eğitim Öğretim ve Yardımlaşma Vakfı Yayını No: 4, İstanbul 1997.

ÖZBEK, Mustafa Serdar: “Ceza Muhakemesi Kanununda Yapılan Değişiklikler Çerçevesinde Mağdur Fail Uzlaştırmasının Usûl ve Esasları”, Ankara Üniversitesi Hukuk Fakültesi Dergisi, 2007, C. 56, Sa. 4, s. 123-205. (ÖZBEK, M. S.).

ÖZBEK, Veli Özer: “Ceza Muhakemesi Hukukunda Uzlaştırma Kurumunun 
6763 Sayılı Kanun Hükümleri Çerçevesinde Değerlendirilmesi”, Ceza Hukuku Dergisi, Sa. 32, Aralık 2016, s. 7-28. (ÖZBEK, V. Ö., 2016).

ÖZBEK, Veli Özer: Ceza Hukukunda Suçtan Doğan Mağduriyetin Giderilmesi, Seçkin Yayınevi, Ankara 1999. (Özbek, V.Ö. 1999).

ÖZGENÇ, İzzet: Türk Ceza Kanunu Gazi Şerhi (Genel Hükümler), Üçüncü baskı, Adalet Bakanlığı yayını, Ankara 2006.

ÖZTÜRK, Bahri/ TEZCAN, Durmuş/ ERDEM, Mustafa Ruhan/ SIRMA GEZER, Özge/ SAYGILAR KIRIT, Yasemin F./ ALAN AKCAN, Esra/ ÖZAYDIN, Özdem/ERDEN TÜTÜNCÜ, Efser/ALTINOK VILLEMIN, Derya/ TOK, Mehmet Can: Nazari ve Uygulamalı Ceza Muhakemesi Hukuku, Güncellenmiş 12. Baskı, Seçkin Yayınevi, Ankara 2018.

POSTACIOĞLU, İlhan E./ ALTAY, Sümer: İcra Hukuku Esasları, Güncelleştirilmiş, Genişletilmiş 5. Bası, Vedat Kitapç1lık İstanbul 2010.

SARI, Rıfat: İcra Suçları, Yayınlanmamış Yüksek Lisans Tezi, Ankara Üniversitesi Sosyal Bilimler Enstitüsü, Ankara 2011.

SOYGÜT ARSLAN, Mualla Buket: Türk Ceza ve Ceza Usul Hukukunda Uzlaşma Kurumu, Galatasaray Üniversitesi Yayınları, İstanbul 2008.

ŞAHIN, Cumhur: "Ceza Muhakemesinde Uzlaşma", Selçuk Üniversitesi Hukuk Fakültesi Dergisi, Konya 1998, C. 6, Sa. 1-2, s. 221-297.

ŞAHIN, Cumhur/ GÖKTÜRK, Neslihan: Ceza Muhakemesi Hukuku -I- , Gözden geçirilmiş ve güncellenmiş 10. Bası, Seçkin Yayınevi, Ankara 2019. (ŞAHIN/ GÖKTÜRK -I).

ŞAHIN, Cumhur/ GÖKTÜRK, Neslihan, Ceza Muhakemesi Hukuku -II, Gözden geçirilmiş ve güncellenmiş 10. Bası, Ankara 2020. (ŞAHINN/ GÖKTÜRK -II).

TOROSLU, Nevzat: Cürümlerin Tasnifi Bakımından Suçun Hukuki Konusu, Ankara Üniversitesi Hukuk Fakültesi Yayınları No. 273, Ankara 1970.

TREBİLCOCK, Michael J./ DANIELS, Ronald J.: Rule of Law Reform and Development Charting the Fragile Path of Progress, Edward Elgar Publishing Limited, Cheltenham -Northampton 2008.

UYAR, Talih: İcra ve İflas Hukukunda Suç Sayılan Fiiller (İcra-İflas Suçları), Şafak Basım ve Yayınevi, Manisa 1987. 
İcra ve İflas Kanununun On Altıncı Babındaki Takibi Şikayete Bağlı Suçlarda...

UYSAL, Mehmet: "Yeni Yasaların Işı̆̆ında İcra ve İflas Suçları", İstanbul Barosu Dergisi, Y1l 2006, Cilt: 80, Sa. 3, s. 1013-1048.

WALDMAN, Ellen A. : "Healing Hearts or Righting Wrongs?: A Meditation on The Goals of "Restorative Justice", Hamline University, Journal of Public Law \& Policy, 2004, Vol. 25, s. 355-374. http://law.hamline.edu (Erişim tarihi: 7/5/2019).

YENISEY, Feridun: Ceza Muhakemesi Hukukunda Uzlaşma (Uzlaştırmacı Eğitimi, Rehber Kitapçı). http:www.uzlaşma.adalet.gov.tr (Erişim tarihi: 8/5/2019).

YILDIZ, Hasan: İcra ve İflas Suçları, Yayınlanmamış Yüksek Lisans Tezi, Selçuk Üniversitesi Sosyal Bilimler Enstitüsü, Konya 2007.

YILMAZ, Ejder: "Borçlunun Sözleşmeden Doğan Yükümlülüğünü Yerine Getirememesine İlişkin Anayasa Hükmü ve İcra ve İflâs Suçları", Prof. Dr. Ergun Önen'e Armağan, Marmara Üniversitesi Hukuk Fakültesi, İstanbul 2003, s. 493-502. 